\title{
Accounting conservatism and corporate governance
}

\author{
Juan Manuel García Lara · Beatriz García Osma • \\ Fernando Penalva
}

\begin{abstract}
We predict that firms with stronger corporate governance will exhibit a higher degree of accounting conservatism. Governance level is assessed using a com posite measure that incorporates several internal and external characteristics. Consistent with our prediction, strong governance firms show significantly higher levels of con ditional accounting conservatism. Our tests take into account the endogenous nature of corporate governance, and the results are robust to the use of several measures of conservatism (market based and nonmarket based). Our evidence is consistent with the direction of causality flowing from governance to conservatism, and not vice versa, indicating that governance and conservatism are not substitutes. Finally, we study the impact of earnings discretion on the sensitivity of earnings to bad news across gover nance structures. We find that, on average, strong governance firms appear to use discretionary accruals to inform investors about bad news in a timelier manner.
\end{abstract}

Keywords Conditional conservatism - Corporate governance · Managerial discretion

JEL Classifications $\quad \mathrm{G} 30 \cdot \mathrm{M} 41$

\author{
J. M. García Lara \\ Department of Business Administration, Universidad Carlos III de Madrid, \\ Calle Madrid 126, 28903 Getafe, Madrid, Spain \\ e-mail: juanmanuel.garcia@uc3m.es \\ B. García Osma \\ Department of Accounting, Universidad Autónoma de Madrid, Fco. Tomás y Valiente 5, \\ Madrid 28049, Spain \\ e-mail: beatriz.garcia@uam.es \\ F. Penalva $(\bowtie)$ \\ IESE Business School, University of Navarra, Av. Pearson 21, Barcelona 08034, Spain \\ e-mail: penalva@iese.edu
}




\section{Introduction}

We examine the association between corporate governance provisions and the incidence of conditional accounting conservatism. Conditional conservatism imposes stronger verification requirements for the recognition of economic gains than for the recognition of economic losses, generating earnings that reflect bad news in a timelier fashion than good news. ${ }^{1}$ In this paper we show that, within a specific institutional or country level demand for accounting based contracts, corporate governance is a significant determinant of firm specific variation in conditional accounting conservatism. Our evidence indicates that the implementa tion of stronger corporate governance provisions results in increased conditional conservatism.

Accounting conservatism benefits the users of financial statements by constrain ing managers' opportunistic payments to themselves and to other parties, mitigates agency problems associated with managerial investment decisions, increases debt and other contracts agreement efficiency, facilitates the monitoring of contracts, and reduces litigation costs (Watts 2003a, b; Ball and Shivakumar 2005). Watts (2003a) argues that the contracting and litigation explanations for the existence of conservatism stem from the fact that the parties to the firm have asymmetric information, asymmetric payoffs, limited liability, and different time horizons. ${ }^{2}$ Conservatism produces accounting numbers that can be used in contracts among the parties to reduce these moral hazard problems. In addition, conservative accounting, on average, defers earnings and generates lower net assets, likely reducing expected litigation costs for the firm.

We posit that corporate governance provisions play an important role in the implementation of accounting conservatism. Corporate governance is the set of mechanisms in place to ensure that the assets of the firm are used efficiently, guaranteeing the suppliers of finance a return on their investment (Shleifer and Vishny 1997) and thus preventing the inappropriate distribution of these assets to managers or other parties at the expense of the rest of the stakeholders. Accordingly, adequate governance results in better monitoring of management. Because of the previously mentioned roles of conservatism in mitigating agency costs and reducing the litigation risk for directors, auditors, and managers, it is expected that efficient

\footnotetext{
1 Following Beaver and Ryan (2005), we refer to this news-dependent conservatism as conditional. Other authors label it as ex post conservatism, income statement conservatism, or earnings conservatism. Unconditional or news-independent conservatism - also labeled ex ante or balance-sheet conservatismin turn, refers to the persistent understatement of shareholders' equity that results from historic cost accounting and underrecognition of certain intangible assets due to the accounting rules (Feltham and Ohlson 1995). In the paper, we only focus on conditional conservatism as it plays a clear role in the contracting and monitoring functions of corporate governance. However, it is difficult to see how contracting is affected by conservatism in the form of an unconditional accounting bias of known magnitude. Rational agents would simply invert the bias. If the bias is unknown, it can only reduce contracting efficiency (Ball and Shivakumar 2005).

${ }^{2}$ Watts (2003b) argues that tax and regulation also contribute to conservatism; however, the empirical evidence thus far offers more limited evidence on the contribution of these factors to conservatism.
} 
corporate governance mechanisms will regard conservatism as a desirable property of accounting numbers and will favor its implementation, demanding reliable accounting information and accelerating the recognition of bad news. Conservative accounting information provides early warning signals to governance bodies such as the board of directors, promoting early investigation into the reasons for bad news.

We predict a positive association between the monitoring role of governance mechanisms and conservatism. Specifically, we expect that the sensitivity of earnings to bad news will be higher for firms with stronger corporate governance. To measure the level of corporate governance, we develop a composite index that takes into account both internal and external indicators, such as the exposure to the market for corporate control and several characteristics of the functioning of the board of directors. We classify firms as having strong (weak) governance if they have low (high) levels of antitakeover protection and low (high) CEO influence on board activity. ${ }^{3}$

To ensure the robustness of our results, we measure conservatism using three proxies. The first one is market based, and the other two are accruals based. We also take into account the endogenous nature of corporate governance and the fact that governance and conservatism may be simultaneously determined. Given the evidence in Bushman et al. (2004), who find a reverse relation between governance structures and the timeliness of earnings, we try to illuminate whether the direction of causality flows from governance to conservatism or vice versa.

Using a large sample of U.S. firms for the period 1992 through 2003, we find that strong (weak) governance firms exhibit a higher (lower) degree of conditional conservatism. Specifically, we document that, compared with their weak gover nance counterparts, strong governance firms have earnings that are significantly timelier in recognizing bad news. Overall, the evidence is consistent with stronger corporate governance structures demanding more conservative accounting infor mation. Our results are also consistent with governance causing conservatism but not vice versa, indicating that governance employs conservatism as a mechanism to fulfill its monitoring role.

We also study whether these differences in the timeliness of earnings to bad news across governance structures are driven by differences across firms in their use of accruals. Using several accruals models, we decompose reported earnings into their nondiscretionary and discretionary components. We find that the increase in conservatism in strong governance firms is driven by the discretionary component of reported earnings. However, we do not find a significant difference in the sensitivity of nondiscretionary earnings to bad news between strong and weak governance firms. Put together, this evidence is consistent with governance characteristics determining managerial use of accruals to accelerate the recognition of bad news.

The rest of the paper is organized as follows. Section 2 discusses the expected association between corporate governance and conservatism. Section 3 contains the research design, developing a metric of governance level and describing the

\footnotetext{
${ }^{3}$ Our use of the expression strong (weak) governance is purely descriptive. It is not intended to mean that strong governance is better than weak governance.
} 
measurement of conservatism and discretionary accruals. Section 4 introduces the sample and presents summary univariate statistics. Section 5 discusses the main results and robustness checks, and Sect. 6 concludes.

\section{Corporate governance and accounting conservatism}

Corporate governance provisions appear as a result of the agency conflict that exists between the parties to the firm. Classic agency theory models these relationships as being fraught with conflicting interests (Berle and Means 1932; Jensen and Meckling 1976; Jensen 1986). Commonly, contracts are written between the parties in an attempt to align their interests. However, these contracts fail to eliminate all agency costs. First, the contracts cannot be complete and thus end up assigning significant residual control rights to managers who, as a result, might expropriate shareholders by, for example, entrenching themselves (Shleifer and Vishny 1997). Second, oftentimes contracts are based on accounting numbers (Watts and Zimmerman 1986), which creates incentives to expedite the recognition of gains and choose aggressive accounting methods. Because of these pervasive differences between the interests and incentives of managers, shareholders, and other providers of finance, corporate governance mechanisms are put in place to reduce agency problems by efficiently monitoring management and contracts.

Conservatism produces numbers that can be used in contracts to mitigate agency costs. Conservative accounting reduces the tendency of managers with short term horizons to invest in negative NPV projects, making managers aware that they will not be able to defer the recognition of losses to the future (Ball and Shivakumar 2005) and imposing greater costs to biasing financial reports upwards (Guay and Verrecchia 2006). Thus, conservative accounting can be used as a mechanism to motivate managers to cut losses earlier and abandon poorly performing projects. In addition, conservative accounting facilitates the monitoring of debt contracts that can be written based on conservative numbers, triggering violations of debt covenants faster (Watts 2003a; Ball and Shivakumar 2005).

Conservative accounting thus increases the efficiency of the contracting between the parties to the firm by limiting the control rights of loss making managers and transferring those rights back to the providers of finance earlier (Ball and Shivakumar 2005). Therefore, the implementation of more conservative accounting choices reduces, at least partly, the agency costs that permeate the relationships amongst the parties to the firm.

Accounting conservatism also can reduce litigation risk. The asymmetric recognition requirements for economic gains and losses are closely linked to asymmetries in the loss function of directors and auditors: overstating (understating) net assets or earnings is more (less) likely to generate litigation costs. Research on auditor litigation shows that lawsuits against auditors are related to overstatements of earnings or net assets (Kellog 1984; St. Pierre and Anderson 1984) or situations of significant income increasing abnormal accruals (Heninger 2001).

We posit that the role of conservatism in mitigating agency costs coupled with its role in reducing litigation risk for managers, directors, and auditors originate a 
demand for conservative accounting numbers at all levels of firm monitoring. Thus, we predict that stronger, more stringent governance structures will favor the implementation of conservative accounting choices. Corporate governance involve ment in the implementation of conservatism is expected to occur both via the demand from the providers of finance for conservative numbers and immediate recognition of bad news and through the constraint of aggressive accounting choices and practices. ${ }^{4}$

We expect that the success of corporate governance in implementing conserva tism hinges vitally on the coordination between internal and external mechanisms. We view effective monitoring as a combination of external and internal provisions. The market for corporate control acts as the main external monitoring device (Fama 1980; Fama and Jensen 1983), whereas efficient boards of directors and the presence of block holders are the most salient internal provisions (Shleifer and Visnhy 1986). It has been argued that the market for corporate control is the most efficient monitor (Jensen 1993), but recent research shows that external and internal governance mechanisms complement each other, and that both types of governance are necessary to guarantee effective monitoring (Mikkelson and Partch 1997; Cremers and Nair 2005). ${ }^{5}$ We expect that both sets of mechanisms will have a role in the implementation of conservatism, as strong external monitoring will increase the efficiency of internal governance mechanisms which, in turn, will be directly responsible for day to day managerial monitoring.

Although there is scarce evidence on the links between conservatism and governance, in line with our expectation that stringent corporate governance provisions result in a higher demand for accounting conservatism, a recent paper by Lobo and Zhou (2006) presents initial evidence of an increase in conservatism as a result of the provisions of the Sarbanes Oxley Act. Also in a similar vein, the work by Beekes et al. (2004) examines the link between accounting quality, measured by earnings timeliness and earnings conservatism, and the proportion of outside directors on the board of U.K. firms. Their results indicate that firms with a higher proportion of outside directors recognize bad news in earnings on a timelier basis.

\footnotetext{
${ }^{4}$ For example, internal governance mechanisms such as independent boards of directors and audit committees have been shown to constrain aggressive practices, limiting the incidence of incomeincreasing earnings management (Beasley 1996; Klein 2002; Peasnell et al. 2005). Similarly, recent research shows that independent audit committees hire better quality auditors (Abbot et al. 2003) that, in turn, impose more conservative accounting choices (Basu et al. 2001; Chung et al. 2003).

5 Literature on this field provides mounting evidence that efficient corporate governance results in lower agency costs and that internal and external governance structures are associated to firm performance. For example, Cremers and Nair (2005) show that firms with strong external and internal governance generate abnormal returns of $10 \%$ to $15 \%$. Core et al. (1999) find that less effective boards of directorscharacterized by the CEO holding the chairman position; larger size; directors appointed by the CEO; and the presence of gray outside directors, old directors, and busy directors-are correlated with higher levels of CEO compensation after controlling for economic determinants of compensation; moreover, they find that predicted excess compensation, based on the governance structure of the firm, is negatively correlated with stock returns 1,3 , and 5 years ahead.
} 
These results are confirmed by Ahmed and Duellman (2007) who document for a U.S. sample that the percentage of inside directors is negatively related to conservatism, and the percentage of outside directors' shareholdings is positively related to conservatism. These results are consistent with our prediction of a positive relation between increased monitoring from corporate governance mechanisms and conservatism.

Alternatively, conservatism could drive corporate governance. Bushman et al. (2004) find that when earnings timeliness is low, boards adopt stronger governance mechanisms as a substitute for high quality accounting information. Even though their measure of earnings timeliness is not a measure of conservatism, their findings seem to suggest that it is the absence of conservatism that causes a strengthening in governance. This view helps explain investors' demand for stronger governance provisions and the existence of stronger governance mechanisms in firms that operate in complex, opaque environments. Nevertheless, they do point out that it is possible that "the direction of causality should be reversed" (p. 195). If this alternative view is accurate, then a negative relation should be expected between governance and conservatism. However, we expect this to be a feedback effect where governance reacts to the absence of conservatism. Our results suggest this feedback effect to be relatively weak compared with our predicted primary effect of a positive relation between governance and conservatism.

\section{Research method}

\subsection{Measurement of corporate governance quality}

We develop a measure of total governance that incorporates attributes of external and internal governance to build our index of governance and classify firms into strong and weak governance structures. We measure the level of governance using an approach similar to the one in Bertrand and Mullainathan (2001) and Davila and Penalva (2006). Specifically, we develop a composite governance variable (Totgov) that incorporates the level of antitakeover protection (external governance) and several characteristics of the board's structure (internal governance). The two types of governance mechanisms (external and internal) are complementary, as both are needed to achieve the desired effects (Cremers and Nair 2005). Our measure of total governance combines the following four proxies:

1. External governance: We proxy the level of external monitoring using the takeover protection index developed by Gompers et al. (2003). We follow Cremers and Nair (2005) and interpret the index as a measure of takeover vulnerability. Using data compiled by the Investors Responsibility Research Center (IRRC) and state takeover law data, Gompers et al. construct a firm specific index by adding one point for every provision that reduces takeover 
vulnerability. ${ }^{6}$ Higher values of this index are associated with more protection against takeovers. Cremers and Nair (2005) also use a narrower alternative takeover index that only accounts for the three components of the IRRC data that are critical to takeovers. They report that their results do not change and conclude that there are no systematic biases in the Gompers et al. index, and that it can be correctly interpreted as a measure of takeover protection.

2. CEO involvement: The Gompers et al. index does not capture information on internal governance, such as board characteristics. Hermalin and Weisbach $(1998,2003)$ argue that the main factor affecting the board's effectiveness is its independence from the CEO. Expanding this argument, we include an indicator variable that takes on the value of one if the CEO is also the chairman of the board and zero otherwise. The CEO has more influence on governance when the same person holds the CEO and chairman titles.

3. Board composition: Previous research finds that independent directors positively influence board decisions. Weisbach (1988) shows that the presence of outside directors is positively related to CEO removal decisions. Byrd and Hickman (1992) find that bidding firms on which independent outside directors hold at least $50 \%$ of the seats have significantly higher announcement date abnormal returns than other bidders. As a second proxy for internal governance, we include the proportion of top executives who serve on the board. Higher proportions of executives on the board are associated with higher CEO influence on governance.

4. Board effectiveness: Adams (2000) and Vafeas (1999) suggest that the number of board meetings is a good proxy for the directors' monitoring effort. We include the inverse of this variable where a higher value is associated with lower board effectiveness.

Following Bertrand and Mullainathan (2001), we define the composite governance variable (Totgov) by taking the unweighted average of the standardized variables. ${ }^{7}$ The standardization is performed to take into account the different scales of the variables that make up the composite measure. Higher values of Totgov are expected to be associated to governance structures with higher antitakeover protection and high CEO influence on board decisions. For brevity, we refer to these structures as weak governance. Conversely, governance structures with low antitakeover protection and low CEO involvement in board decisions are referred to as strong governance. These meanings are attached to the terms "weak governance" and "strong governance" throughout the paper.

\footnotetext{
${ }^{6}$ Gompers et al. (2003) examine 24 provisions: anti-greenmail, blank-check preferred stock, business combination laws, bylaw and charter amendment limitations, classified board, compensation plans with change in control provisions, director-indemnification contracts, control share cash-out laws, cumulative voting requirements, director's duties, fair-price requirements, golden parachutes, director indemnification, limitations on director liability, pension parachutes, poison pills, secret ballots, executive severance agreements, silver parachutes, special meeting requirements, supermajority requirements, unequal voting rights, and limitations on action by written consent.

${ }^{7}$ Like Bertrand and Mullainathan (2001), we use unit weights to construct Totgov following the recommendations of Grice and Harris (1998), who find that unit-weighted composites exhibit better psychometric properties than alternative weighting schemes.
} 


\subsection{Measurement of accounting conservatism}

To test the association between corporate governance quality and accounting conservatism, we analyze conservatism using three different proxies. This section describes the measures used to capture conditional conservatism.

\subsubsection{Conditional conservatism based on Basu (1997)}

Our first measure of conservatism is based on Basu's (1997) measure. Under conservative accounting, earnings capture bad news faster than good news because of the asymmetric standards of verification of losses and gains. Basu uses stock returns to proxy for good and bad news. Stock prices incorporate all the information arriving in the market from multiple sources in a timely fashion, including reported earnings. Therefore, stock price changes are a measure of news arrival during the period. Because earnings are timelier in recognizing bad news than good news, Basu expects to find a higher association of earnings with negative returns (his bad news proxy) than with positive returns (the good news proxy). We use Basu's regression as follows (firm sub indexes are understood):

$$
X_{t}=\beta_{0}+\beta_{1} D_{t}+\beta_{2} R_{t}+\beta_{3} D_{t} R_{t}+\mu_{t}
$$

where $X_{t}$ is earnings per share before extraordinary items and discontinued operations deflated by share price at the beginning of the period; $R_{t}$ is the stock rate of return of the firm, measured by compounding 12 monthly CRSP stock returns ending the last day of fiscal year $t ; D_{t}$ is a dummy variable that equals one in the case of bad news (negative or zero market adjusted stock rate of return) and zero in the case of good news (positive market adjusted stock rate of return). The coefficient $\beta_{3}$ measures the level of asymmetric timeliness of conservatism and it is expected to be positive and significant. ${ }^{8}$

In a recent study, Dietrich et al. (2007) claim that the Basu specification is biased and that inferences based on it should not be relied upon. The bias seems to be caused by the method used to partition the sample and by the choice of deflator for the variables in the regression. For these reasons, they suggest the use of alternative measures to validate the robustness of inferences drawn with the Basu approach. We do so in Sect. 3.2.2, in which we follow Ball and Shivakumar (2005) and use their measure of conditional conservatism based on the relation between accruals and cash flows, and in Sect. 3.2.3, in which we use a measure developed by Givoly and Hayn (2000) based on the accumulation of operating accruals.

\footnotetext{
${ }_{8}$ Prior studies (Givoly et al. 2007; Callen et al. 2006) express their distrust of inferences drawn from the Basu (1997) model if used in a time-series (firm-specific) approach. We use a cross-sectional approach.
} 
Despite the concerns raised by Dietrich et al. (2007), Ryan (2006) argues that the biases introduced by the Basu approach are likely to be small. ${ }^{9}$ To ameliorate these concerns, we follow the recommendations of Ryan (2006) and use market adjusted returns, defined as raw returns minus the value weighted CRSP market return, to create the partitioning dummy variable $D$ in the Basu regression. The reason for using adjusted returns to partition the sample instead of raw returns, as is more common in the conservatism literature, is the evidence in Dietrich et al., who show that partitioning a regression sample with one of the regressors $\left(R_{t}\right)$ may produce biased inferences. They also argue that inferences from Basu's reverse regression might be biased due to earnings driving returns. As an additional precaution, following Ryan (2006), we measure returns over the fiscal year. This partially removes the impact of the annual earnings announcement over stock prices, which occurs approximately 3 months after closing. However, we report that our inferences are not affected by the use of raw or adjusted returns or by the choice of the measurement window. ${ }^{10}$

Although the evidence in Dietrich et al. highlights that additional research is needed regarding which is the proper specification of earnings returns regressions to measure conditional conservatism, the results of prior research support the notion that the potential biases are small. In fact, there is a wealth of recent research that uses the Basu measure of conservatism (Pope and Walker 1999; Ball et al. 2000, 2003; Givoly and Hayn 2000; Holthausen and Watts 2001; Ryan and Zarowin 2003; Raonic et al. 2004; Bushman and Piotroski 2006; Roychowdhury and Watts 2006; among many others), that obtains empirical evidence in accordance with the extant theories. Many of these theories have also been supported by research designs that do not rely on the Basu approach. In our case, the results are not affected by the method used to measure conditional conservatism, and the three approaches yield identical inferences consistent with good governed firms showing higher conditional conservatism.

To assess whether there are significant differences across governance structures, we modify Eq. 1 to include the level of total governance, Totgov, as an interaction term as follows:

\footnotetext{
${ }^{9}$ Ryan (2006, Footnote 2) states that "two well-known empirical results together imply the biases identified by Dietrich et al. are likely to be fairly small and so biases in returns-based measures of asymmetric timeliness are likely to be correspondingly small. First, the low R2s observed in contemporaneous returns-earnings regressions suggest that the extent to which earnings causes returns is tiny compared to the extent to which both variables are determined by other, more primitive information. Second, a large literature, only some of which employs the reverse regressions of earnings on returns used to estimate asymmetric timeliness, exists that shows returns typically reflect information on a timelier basis than earnings."

${ }^{10}$ Basu uses the annual stock rate of return measured from 9 months before fiscal year end $t$ to 3 months after fiscal year-end $t$. However, most subsequent studies use the fiscal year. Measuring returns 3 months after fiscal year-end is aimed at giving time to the market to incorporate information in contemporaneous earnings. Using fiscal year returns avoids returns being distorted by new information (different from earnings) coming to the market. Our results are not affected by this choice.
} 


$$
\begin{aligned}
X_{t}= & \beta_{0}+\beta_{1} D_{t}+\beta_{2} \text { Totgov }_{t}+\beta_{3} R_{t}+\beta_{4} D_{t} \text { Totgov }_{t}+\beta_{5} R_{t} \text { Totgov }_{t}+\beta_{6} D_{t} R_{t} \\
& +\beta_{7} D_{t} R_{t} \text { Totgov }_{t}+\mu_{t}
\end{aligned}
$$

We expect to observe differences in conservatism between strong and weak governance firms, that is, firms with low and high values of Totgov, respectively. In particular, we hypothesize that the asymmetric timeliness coefficient $\beta_{6}$ will be positive and significant and that $\beta_{7}$ will be negative. Thus, the total conservatism $\left(\beta_{6}+\beta_{7}\right)$ of weak governance firms will be smaller than that of strong firms, because higher values of Totgov are associated with weaker governance.

\subsubsection{Conditional conservatism based on Ball and Shivakumar (2005)}

Our second measure of conservatism is based on the approach suggested by Ball and Shivakumar (2005) who use regressions based on accruals and cash flows. This approach presents the advantage of not relying on market measures, thereby reducing the risk of drawing incorrect inferences due to market inefficiencies.

The asymmetrical treatment of economic gains and losses also generates an asymmetry in accruals. Ball and Shivakumar (2005) argue that the negative association between earnings and operating cash flows first documented by Dechow (1994) is less pronounced in bad news periods as a consequence of the asymmetric verification requirements to recognize good and bad news in earnings. Economic losses are likely to be recognized on a timely basis through unrealized accruals, while economic gains are recognized when realized and thus accounted for on a cash basis. To test the asymmetry in accruals Ball and Shivakumar propose the following model:

$$
\text { Accr }_{t}=\beta_{0}+\beta_{1} D C F O_{t}+\beta_{2} C F O_{t}+\beta_{3} C F O_{t} D C F O_{t}+\mu_{t}
$$

where Accr denotes annual total accruals, defined as income before extraordinary items minus cash flow from operations and where both variables are extracted from the statement of cash flows. Accr and $C F O$ are both scaled by average total assets. To control for the great variation in the type and size of accruals across industry groups, we adjust $A c c r$ and $C F O$ by subtracting the two digit SIC industry mean of each variable every year. $D C F O$ is a dummy variable equal to one in the case of negative $C F O$ and zero otherwise. In this model, $\beta_{2}$ is expected to be significantly negative showing the expected negative correlation between accruals and cash flows, and $\beta_{3}$ is expected to be significantly positive in the presence of conditional conservatism, showing a positive contemporaneous association between cash flows and accruals in bad news periods, that is, that accrued losses are more likely in periods of negative cash flows.

As before, we augment the Ball and Shivakumar (2005) model by interacting all variables with total governance, Totgov, as follows:

$$
\begin{aligned}
& \text { Accr }_{t}=\beta_{0}+\beta_{1} \text { DCFO }_{t}+\beta_{2} \text { Totgov }_{t}+\beta_{3} \text { CFO }_{t}+\beta_{4} \text { DCFO }_{t} \text { Totgov }_{t} \\
& +\beta_{5} \text { CFO }_{t} \text { Totgov }_{t}+\beta_{6} \text { DCFO }_{t} \text { CFO }_{t}+\beta_{7} \text { DCFO }_{t} \text { CFO }_{t} \text { Totgov }_{t}+\mu_{t}
\end{aligned}
$$


We expect to observe differences in conservatism between strong and weak governance firms. In particular, we hypothesize that the asymmetric timeliness coefficient $\beta_{6}$ will be positive and significant and that $\beta_{7}$ will be negative. Thus, the total conservatism $\left(\beta_{6}+\beta_{7}\right)$ of weak governance firms will be smaller than that strong firms, because higher values of Totgov are associated with weaker governance.

\subsubsection{Conditional conservatism based on Givoly and Hayn (2000)}

Our third measure of conservatism is based on Givoly and Hayn (2000) who find that higher accounting conservatism results in more negative total accruals. To reduce the effect of temporary large accruals, which tend to reverse in one or two years (Richardson et al. 2005), our measure of conservatism, $A v g$ Accr $_{t}$, is defined as the three year average of total accruals, over a period centered at year $t$. This measure presents two advantages: it is not market based, and it is firm year specific. The measure is not industry adjusted as we explicitly control for industry effects in all our regression analyses. Notice that $A v g$ Accr $_{t}$ is a measure of total conservatism, rather than conditional conservatism. However, only conditional conservatism has a clear governance role (Ball and Shivakumar 2005). Therefore, to the extent that this measure captures conditional conservatism with some noise, it would induce a bias against finding an association between governance and conservatism.

To assess the impact of governance on conservatism, we use the following specification:

$$
\begin{aligned}
\text { AvgAccr }_{t}= & \alpha \text { Totgov }_{t-1}+\beta \text { Controls }_{t-1}+\gamma \text { Industry dummies } \\
& +\delta \text { Year dummies }+\mu_{t}
\end{aligned}
$$

In further tests of robustness, we also estimate this equation in levels and changes, adding up to three lags of AvgAccr and Totgov. Specifying the equation in changes minimizes the effect of omitted variables that remain relatively constant over time such as industry variables and firm specific factors. We expect coefficient $\alpha$ to be significantly positive as weaker governance (that is, higher values of Totgov) is associated with lower conservatism (that is, more positive AvgAccr).

The control variables, Controls, are a vector of determinants of conservatism considered in previous research (Dechow and Dichev 2002; Francis et al. 2004): firm size, cash flow variability, sales variability, length of the operating cycle, intangibles intensity, absence of intangibles, and capital intensity. We measure the determinants as in Francis et al. (2004). Firm size is the log of total assets (LogAssets). The proxy for cash flow variability is the standard deviation of the firm's rolling 10 year cash flows from operations (StdCFO), scaled by total assets. Sales variability is computed as the standard deviation of rolling 10 year sales revenues (StdSales), scaled by total assets. The length of the operating cycle is measured as the log of the sum of the firm's days of receivables and days of inventory (OperCycle). The intensity of intangibles is captured by the sum of the firm's reported R\&D and advertising expenses (Int Intensity), scaled by total sales (missing values of these items are set to zero). The absence of intangibles 
is measured with an indicator variable (Int Dummy) that takes on the value of one if the intensity of intangibles is zero, and zero otherwise. Capital intensity is calculated as the gross book value of property, plant, and equipment (Cap Intensity) scaled by total assets. We also include an indicator variable (Big 5) that equals one if the firm's auditor is one of the Big Five, and zero otherwise. Finally, two digit SIC industry and fiscal year indicator variables are also added. ${ }^{11}$

\subsection{Governance self selection issues}

Our main hypothesis is that governance and conservatism are positively associated because governance structures demand conservatism to achieve the desired monitoring and control benefits. However, there is an alternative hypothesis that yields the opposite prediction. Management may try to compensate for otherwise weak governance by strengthening conditional conservatism, generating a negative association between governance and conservatism. In certain contexts, this could be an optimal arrangement for the firm. For example, consider a situation in which firm specific expertise at the board level is relatively important (for example, the firm manufactures a very sophisticated product). In this case, considering the board's dual duty of advising and monitoring, the firm may benefit from having on its board a higher proportion of executives, capable of providing sound technical advice. To the extent that this reduces the board's monitoring ability, the firm may increase conservatism so that external parties can better oversee management. In this situation, weak governance and high conservatism go hand in hand. ${ }^{12}$ However, it is unlikely that this is the case in most firms. If our sample contains a few firms in a situation like the one just described, this would work against our main hypothesis. Discriminating between the two competing hypotheses becomes an empirical question that we revisit in Sect. 5.

The above illustration of the alternative hypothesis highlights that governance is an endogenous variable because it depends on firm and contracting environment characteristics, and some of these characteristics may also drive the degree of accounting conservatism. Because the selection of the level of governance is not random, not controlling for this potential self selection problem may bias the inferences in an unknown direction, particularly in levels regressions.

To reduce this risk we use the two step Heckman (1979) procedure. In the first stage, governance choice is modeled using a probit model. In particular, we regress a dummy variable that indicates whether the firm has selected either to have strong or weak governance on a set of determinants. We define strong (weak) governance as having values of Totgov below (above) the median of this variable. In the second stage, we estimate the Eqs. 15 including as an additional control variable the inverse Mills ratio computed from the parameters of the first stage.

\footnotetext{
${ }^{11}$ The inclusion of additional control variables such as the incidence of losses and earnings variability (Francis et al. 2004) does not change the inferences. Neither does including as a proxy for growth opportunities, the book-to-market value of assets ratio. We exclude this last variable because it also captures a certain degree of conservatism.

${ }^{12}$ We are grateful to an anonymous referee for this insight.
} 
The determinants of governance are taken from previous literature: firm size (Demsetz and Lehn 1985); growth opportunities (Smith and Watts 1992); firm age (Bushman et al. 2004); free cash flow (Jensen 1986; Lang et al. 1991); idiosyncratic risk (Demsetz and Lehn 1985); leverage (Cremers and Nair 2005); industry concentration and geographic concentration (Bushman et al. 2004); CEO tenure (Hermalin 2005); firm performance (Hermalin and Weisbach 1988; Demsetz and Lehn 1985); auditor size (Basu et al. 2001); regulated industry (Demsetz and Lehn 1985; Bushman et al. 2004); high tech industry (Chandra et al. 2004). Finally, we include indicator variables for the fiscal year. Appendix 1 contains the measurement details of each variable.

\subsection{Use of discretionary accruals across governance structures as a signaling mechanism}

Research on corporate governance has found that firms with weak governance structures engage in more earnings manipulation, that is, they have lower quality earnings and accruals (for example Dechow et al. 1996; Becker et al. 1998; Klein 2002; Peasnell et al. 2005). However, Bowen et al. (2004) find that, on average, variation across governance structures in the use of discretionary accruals is not driven by opportunistic reasons; rather, accruals are used as a signal to convey information to the market. This is consistent with managers using discretionary accruals to make accounting information more relevant, aligning earnings and returns (Guay et al. 1996). Based on these findings, we hypothesize that stronger governance structures provide managers with incentives to make more conservative accounting choices by using discretionary accruals. To test this prediction, we run Eqs. 2, 4, and 5, taking into account the possible effect of earnings discretion on asymmetric timeliness.

To disentangle the effects of earnings discretion and conservatism, we start from the simple accounting equality that earnings equal cash flows plus total accruals $\left(X_{t}=C F O_{t}+T A C C_{t}\right)$. Given that cash flows are typically considered objective evidence (easy to verify information), differences in conservatism across firms are accomplished through accruals. Accountants will use accruals to make earnings timelier. ${ }^{13}$ Accruals can be further decomposed into nondiscretionary (normal) and discretionary (abnormal) components. Several discretionary accruals models are used in the literature, and there is currently much debate on the appropriateness of the different methods. It is beyond the scope of this paper to enter this controversy. We estimate discretionary accruals using four methodologies as a check for robustness: the (i) total and (ii) working capital accruals versions of the modified Jones (1991) model (Dechow et al. 1995), the (iii) Kasznik (1999) model and the (iv) lagged return on assets modification suggested by Kothari et al. (2005). In this

13 Managers may also manipulate the timing and level of cash flows (e.g., Roychowdhury 2006; Bushee 1998; Bartov 1993), however, due to its low flexibility and high visibility, this is expected to be a residual form of earnings management (Peasnell et al. 2000). 
way, we expect to minimize the likelihood of our results being driven by the particular choice of discretionary accruals estimation method.

To perform our tests on the influence of earnings discretion on conservatism across governance structures, we replace the dependent variable in Eqs. 1 5, as in García Lara et al. (2005), with its pre discretionary accruals version. For instance, for the dependent variable of the Basu approach, the dependent variable becomes $X_{t}^{*}\left(=X_{t} \quad D A X_{t}\right)$, where $D A X$ is one of the estimated proxies for discretionary accruals. If discretionary accruals are one of the tools used by management to achieve a higher level of conservatism in strong governance firms, we do not expect to find significant differences in the asymmetric timeliness coefficient across governance structures when the dependent variable in the regression of interest is measured removing the effect of discretionary accruals $\left(X_{t}^{*}, \operatorname{Accr}_{t}^{*}, \operatorname{AvgAccr}_{t}{ }^{*}\right)$.

\section{Sample description}

Accounting data are taken from the 2003 version of Compustat. Market return data are taken from CRSP. Board characteristics and CEO data come from the 2003 version of Execucomp. The antitakeover protection index constructed by Gompers et al. (2003) with IRRC data was downloaded from Andrew Metrick's web page. ${ }^{14}$ The Execucomp and the IRRC data cover approximately 1,500 firms that make up the S\&P 500, MidCap and SmallCap indices. We eliminate firms with a negative book value of equity and firms in the financial sector (SIC 6000 6999) because the discretionary accrual methods are not appropriate for these firms. To reduce the adverse effect of outliers, all continuous variables are winsorized annually at the top and bottom percentile of their distributions. The intersection of these databases and the additional data requirements yield a sample that contains 9,152 firm year observations for the period 1992 through 2003, corresponding to 1,611 different firms.

Table 1 contains the summary statistics of the variables used in our tests of the association between conservatism and governance. Panel A contains the variables used in the Basu (1997) and Ball and Shivakumar (2005) regressions and the governance variables. Panel B contains the variables used in the Givoly and Hayn (2000) regression, which uses a firm year measure of conservatism and control variables. In Panel B, the reduction in sample size to 6,297 observations is due to the additional data requirements of some variables which require 10 continuous years of observations. The summary statistics for firms in the sample indicate that, on average, they have nine antitakeover provisions, the board meets seven times per year, $32 \%$ of the board is made up of executives, and the CEO is also the chairman

\footnotetext{
14 Our data covers the period 1992 through 2003. The IRRC data is only available for 1990, 1993, 1995, 1998, 2000, and 2002. Gompers et al. (2003) report that for the majority of firms there is little time-series variation in the index. Taking advantage of this fact, like Cremers and Nair (2005), we align the index values available for 1990 with firm data for 1992, the index values for 1993 with firm data for 1993 and 1994, the index values for 1995 with firm data for 1995, 1996, and 1997, the index values for 1998 with firm data for 1998 and 1999, the index values for 2000 with firm data for 2000 and 2001, and the index values for 2002 with firm data for 2002 and 2003.
} 


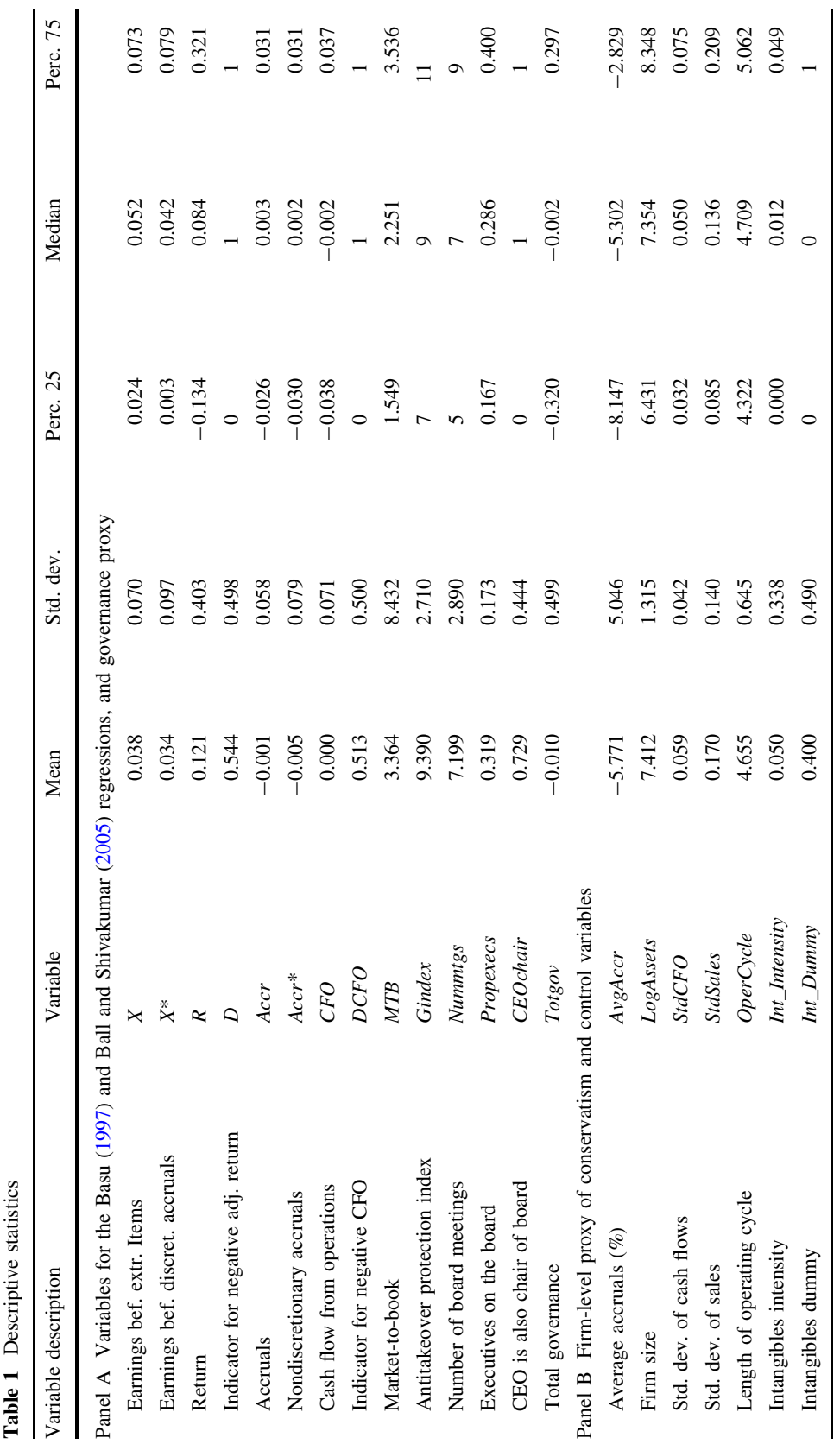




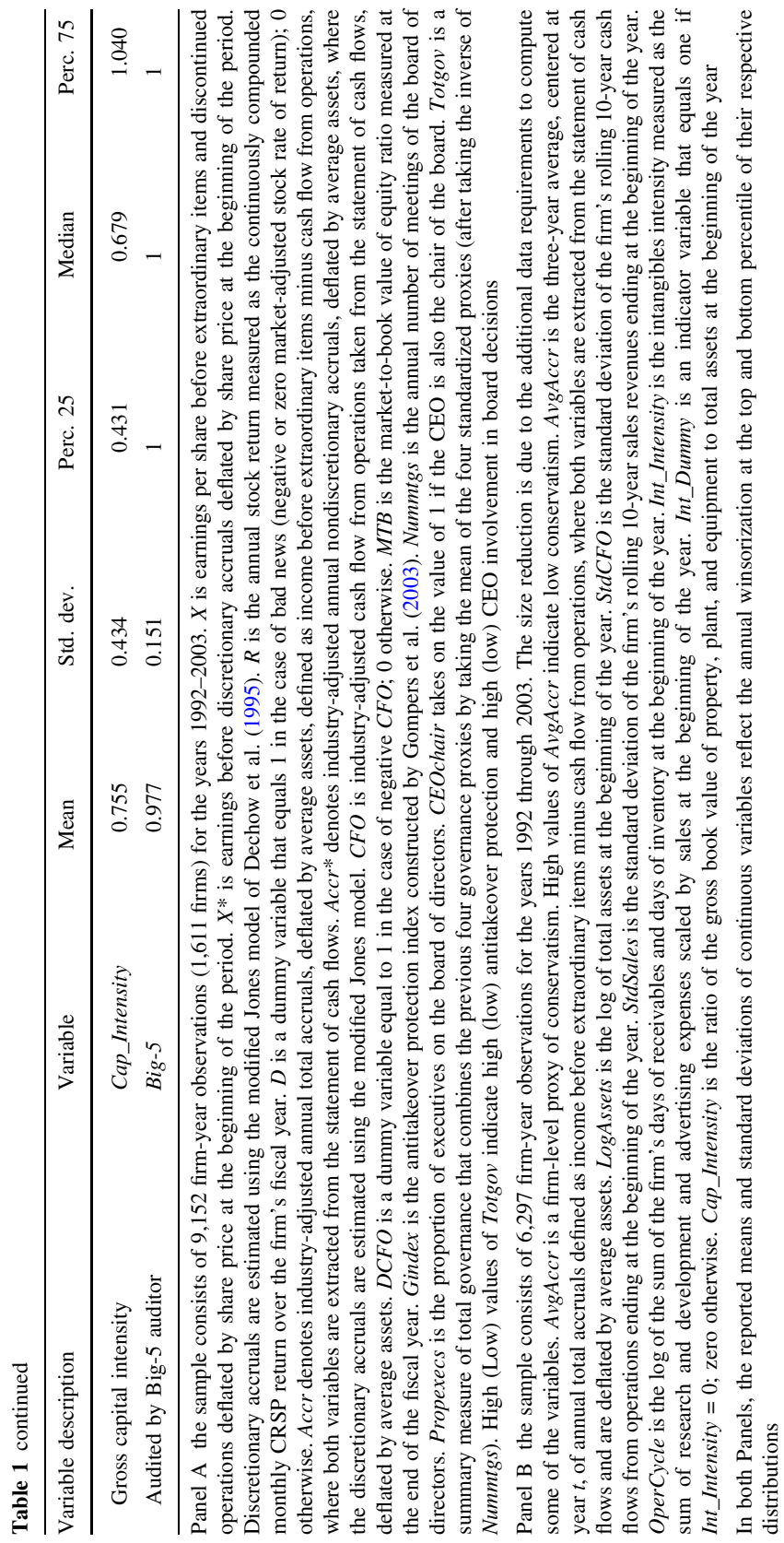


of the board $73 \%$ of the time. The mean market to book ratio is 3.4 , indicating the presence of substantial conservatism and growth opportunities. Consistent with the existence of conservatism, earnings are negatively skewed (medians exceed means). We observe the same phenomenon in industry adjusted accruals (Accr) which are negatively skewed and in earnings and accruals before discretionary accruals. The firm level proxy of conservatism ( $\mathrm{AvgAccr}$ ) is strongly negative, 5.77, consistent with the presence of conservatism. As for the control variables, the average log of total assets is 7.41 ( $\$ 1,656$ million) indicating that sample firms are fairly large, and the mean of the variability in operating cash flows and sales is 0.06 and 0.17 respectively. The mean operating cycle is equivalent to 105 days. The mean value of the intangibles intensity is 0.05 , and $40 \%$ of the sample firms report zero expenditures in $R \& D$ and advertising (intangibles dummy). The average gross capital intensity equals 0.75 . Finally, almost $98 \%$ of the sample firms are audited by a Big Five auditor.

\section{Empirical results}

5.1 Differences in conditional conservatism across governance structures and the influence of earnings discretion

Table 2 contains the results of the estimation of Eqs. 2 and 4 that assess the association between governance and conservatism. The table shows the estimation results using pooled Heckman regressions, which take into account the endogeneity of governance choice. The first stage probit regression results are reported in Appendix 1 and then omitted from the Tables for parsimony. The $z$ statistics reported in the regressions are based on standard errors robust to both heterosced asticity and within group serial correlation (Rogers 1993).

Panel A shows the results for the Basu conservatism proxy. When the dependent variable is earnings, $X$, the $\beta_{6}$ coefficient that captures asymmetric timeliness is positive and significant; the $\beta_{7}$ coefficient is negative and also significant, indicating that weak governance (that is, high Totgov) is associated with lower conditional conservatism. It is worthwhile to notice the small size $(0.01)$ of the positive returns coefficient $\beta_{3}$ and the much larger size of the negative returns coefficient $\beta_{6}(0.07)$. This is consistent with recent evidence (Basu 1997; Ball et al. 2000). Interpreting this evidence, Watts (2003b, p. 292) concludes that in recent years "U.S. firms' accounting earnings are not timely at all in reflecting good news but are timely in reflecting bad news." However, when the dependent variable is earnings before discretionary accruals, $X^{*}$, the coefficient $\beta_{7}$ becomes insignificantly different from zero, suggesting that there is no difference in conservatism once discretionary accruals are removed. ${ }^{15}$ This is in agreement with our prediction that managers of firms with strong governance will use the discretion inherent to the estimation of

\footnotetext{
15 For parsimony, we only report the results that use the modified Jones model of Dechow et al. (1995) to estimate discretionary accruals. The results are not affected by the choice of accruals estimation method.
} 
Table 2 Heckman estimation of the asymmetric timeliness across governance structures. Assessing asymmetric timeliness as a function of the level of total governance. Estimation of the Basu (1997) and the Ball and Shivakumar (2005) regressions interacted with the governance proxy Totgov

\begin{tabular}{|c|c|c|c|c|c|c|c|}
\hline \multirow[t]{2}{*}{ Panel A } & & \multicolumn{2}{|c|}{ Dependent variable } & \multirow{2}{*}{\multicolumn{2}{|c|}{ Panel B }} & \multicolumn{2}{|c|}{ Dependent variable } \\
\hline & & $X$ & $X^{*}$ & & & Accr & Accr* \\
\hline \multirow[t]{2}{*}{ Constant } & $\beta_{0}$ & 0.02 & 0.00 & Constant & $\beta_{0}$ & 0.01 & 0.01 \\
\hline & $z$-stat & 5.27 & 0.26 & & $z$-stat & 2.03 & 0.37 \\
\hline \multirow[t]{2}{*}{$D$} & $\beta_{1}$ & 0.01 & 0.01 & $D C F O$ & $\beta_{1}$ & 0.01 & 0.00 \\
\hline & $z$-stat & 3.81 & 1.59 & & $z$-stat & 3.83 & 0.44 \\
\hline \multirow[t]{2}{*}{ Totgov } & $\beta_{2}$ & 0.02 & 0.00 & Totgov & $\beta_{2}$ & 0.01 & 0.00 \\
\hline & $z$-stat & 2.60 & 0.22 & & $z$-stat & 1.67 & 0.30 \\
\hline \multirow[t]{2}{*}{ Return } & $\beta_{3}$ & 0.01 & 0.03 & $\mathrm{CFO}$ & $\beta_{3}$ & 0.36 & 0.18 \\
\hline & $z$-stat & 2.34 & 3.54 & & $z$-stat & 10.03 & 3.76 \\
\hline \multirow[t]{2}{*}{$D \times$ Totgov } & $\beta_{4}$ & 0.02 & 0.00 & $D C F O \times$ Totgov & $\beta_{4}$ & 0.01 & 0.00 \\
\hline & $z$-stat & 2.11 & 0.00 & & $z$-stat & 1.63 & 0.22 \\
\hline \multirow[t]{2}{*}{ Return $\times$ Totgov } & $\beta_{5}$ & 0.01 & 0.02 & $C F O \times$ Totgov & $\beta_{5}$ & 0.02 & 0.08 \\
\hline & $z$-stat & 0.79 & 1.44 & & $z$-stat & 0.29 & 0.89 \\
\hline \multirow[t]{2}{*}{$D \times$ Return } & $\beta_{6}$ & 0.07 & 0.04 & $D C F O \times C F O$ & $\beta_{6}$ & 0.24 & 0.26 \\
\hline & $z$-stat & 5.02 & 2.60 & & $z$-stat & 2.72 & 2.63 \\
\hline \multirow{2}{*}{$\begin{array}{r}D \times \text { Return } \\
\quad \times \text { Totgov }\end{array}$} & $\beta_{7}$ & 0.07 & 0.04 & $D C F O \times C F O$ & $\beta_{7}$ & 0.46 & 0.20 \\
\hline & $z$-stat & 2.53 & 1.50 & $\times$ Totgov & $z$-stat & 2.64 & 0.83 \\
\hline Inverse Mills ratio & $z$-stat & 12.11 & 5.56 & Inverse Mills ratio & $z$-stat & 3.50 & 0.40 \\
\hline
\end{tabular}

The sample consists of 9,152 firm-year observations (1,611 firms) for the years 1992 through 2003. In Panel A, $X$ is earnings per share before extraordinary items and discontinued operations deflated by share price at the beginning of the period. $X^{*}$ is earnings before discretionary accruals deflated by share price at the beginning of the period. The discretionary accruals are estimated using the modified Jones model of Dechow et al. (1995). $R$ is the annual stock return measured as the continuously compounded monthly CRSP return over the firm's fiscal year. $D$ is a dummy variable that equals one in the case of bad news (negative or zero market-adjusted stock rate of return); zero otherwise. In Panel B, Accr denotes industryadjusted annual total accruals, deflated by average assets, defined as income before extraordinary items minus cash flow from operations, where both variables are extracted from the statement of cash flows. $A c c r^{*}$ denotes industry adjusted annual nondiscretionary accruals, deflated by average assets, where the discretionary accruals are estimated using the modified Jones model. $C F O$ is industry-adjusted cash flow from operations taken from the statement of cash flows, deflated by average assets. $D C F O$ is a dummy variable equal to one in the case of negative $C F O$ and zero otherwise. In both Panels, Totgov is a summary measure of total governance. High (Low) values of Totgov indicate high (low) antitakeover protection and high (low) CEO involvement in board decisions. The (unreported) first stage of the Heckman procedure models governance choice with a dummy variable that indicates whether the firm has selected to have strong or weak governance. Strong (weak) governance denotes that the firm has a total governance score below (above) the median of Totgov. The determinants of governance choice are size, growth opportunities, firm's age, presence of large free cash flows, idiosyncratic risk, leverage, industry concentration, geographic concentration, CEO tenure, firm's stock performance, whether the firm is in a regulated industry, whether the firm is in a high technology industry, whether the firm is audited by a Big Five auditor, and indicator variables for the fiscal year

The reported $z$-statistics in italics are based on standard errors which are robust to both heteroscedasticity and within-group serial correlation. The two-sided thresholds of the $z$-statistics for significance at the $0.10,0.05$, and 0.01 confidence levels are $1.64,1.96$, and 2.61 , respectively 
accruals, in addition to other means, to increase the level of conditional conservatism.

The inverse Mills ratios of both regressions are significant, justifying the endogeneity concerns. However, if we repeat the estimation of these regressions without including the inverse Mills ratios or using Fama and MacBeth (1973) mean annual regressions, the inferences do not change. ${ }^{16}$ The same is true when we employ the methodology of Roychowdhury and Watts (2006). These authors show that the Basu proxy is a better measure of conservatism when estimated cumulatively over several periods, as it reduces the influence of rents on the asymmetric timeliness coefficient. Following these authors, we repeat our previous tests estimating the Basu measure by cumulating earnings and returns over the past three years. The inferences drawn from Panel A of Table 2 are identical. This confirms that our previous findings are not driven by the noise contained in the Basu measure.

To further address the concerns raised by Dietrich et al. (2007) about Basu's conservatism proxy, we alternatively substitute price deflated accruals and price deflated cash flow for price deflated earnings in the Basu regression Eq. 2. Given our hypothesis that stronger governance leads to more conservative accounting choices and that these choices are implemented through accruals, we should expect that, if Basu's model correctly captures conservatism, the $\beta_{7}$ coefficient of the governance interaction term would be smaller in the regression using cash flow as a dependent variable. Untabulated results confirm this notion. In fact, $\beta_{7}$ is insignificantly different from zero in the cash flow specification ( $p$ value $=0.468$ ), while it is significantly negative in the accruals specification ( $p$ value $=0.004$ ). This confirms that Basu's proxy is not seriously affecting the inferences about the presence of conditional conservatism and that the biases documented by Dietrich et al. seem to be small in our sample, as predicted by Ryan (2006). Overall, this evidence is consistent with (1) a positive association between the quality of corporate governance and conditional conservatism, (2) accruals playing a significant role in the asymmetric timeliness of earnings, and (3) strongly governed firms using their discretion over accruals to make earnings timelier to bad news. ${ }^{17}$

Panel B of Table 2 depicts the results of the pooled Heckman estimation of regression (4). As predicted, when the dependent variable is accruals, the coefficient that captures asymmetric timeliness, $\beta_{6}$, is positive and significant, and the coefficient that shows the association of governance and conservatism, $\beta_{7}$, is significantly negative, indicating that weak governance reduces conditional

\footnotetext{
${ }^{16}$ Fama and MacBeth (1973) regressions should be interpreted with caution. Basu (1999) gives a number of reasons against the use of mean annual regressions, related mainly to the parameters not being stationary.

17 Our estimate of discretionary accruals is based on the modified Jones model. This model only controls for two simple relations: between accruals and sales and accruals and property, plant, and equipment. This model would rarely capture other possible drivers of conservatism such as special items (restructuring charges and other one-time items). Managers also may use special items to affect conservatism. To assess this possibility, we augment earnings and the discretionary accruals estimate by adding the special items (Compustat item \#17) deflated by beginning-of-the-period market value of equity. Then, we repeat the tests in Panel A of Table 2. Untabulated results indicate that the inferences still hold.
} 
conservatism. If we remove the effect of discretion in accruals, in the last column of Panel B we can observe that coefficient $\beta_{7}$ becomes insignificant. The inverse Mills ratio of the first regression is also significant, confirming the appropriateness of the self selection controls. However, repeating these tests without this control does not alter the conclusions. We also obtain the same result using Fama and MacBeth regressions.

We also conduct a sensitivity test of the total governance measure Totgov. We want to assess the individual contribution of the external and internal governance components of the measure, as they might be closely related. For instance, external governance is likely to lead to internal governance. Therefore, we construct a measure of internal governance taking the average of the three proxies of internal governance and a measure of external governance using only the standardized Gompers et al. (2003) index. Then, we estimate Eqs. 2 and 4 substituting alternatively internal governance and external governance for total governance. The untabulated results indicate that both components contribute significantly, as the interaction coefficient $\beta_{7}$ is always negative and significant, confirming that both internal and external governance play a significant role in the implementation of conditional conservatism.

Table 3 contains the estimation of Eq. 5, which uses a firm level proxy of conditional conservatism. This regression presents the additional advantage of allowing for the direct inclusion of control variables that may affect the level of conservatism. The first column shows that coefficient $\alpha$ is strongly positive and significant, confirming our prediction of a positive association between governance and conservatism. ${ }^{18}$ The inverse Mills ratio of this regression is highly significant, consistent with the presence of endogeneity in governance. Nevertheless, removing the inverse Mills ratio from the tests does not alter the inferences. If we remove the effect of discretion in our conservatism proxy, in the second column we observe that the significance of coefficient $\alpha$ goes away, and it even has the wrong sign. This is one more piece of evidence consistent with managers using discretionary accruals to affect the level of conservatism. For completeness, in Appendix 2 Panels A to C, we report the results of estimating models (2), (4), and (5) respectively using discretionary accruals as the dependent variable. The coefficients $\beta_{7}$ in Panels $\mathrm{A}$ and $\mathrm{B}$, and $\alpha$ in Panel $\mathrm{C}$ that capture the association between governance and conditional conservatism are significant and with the correct sign.

To summarize, in this section we tested the association between governance and conditional conservatism using three different proxies of conservatism (market based and nonmarket based), with and without controls for potential problems of self selection of governance choice, and applying different methodologies. All the tests confirm our main hypothesis of a positive association between governance and conservatism and reject the alternative hypothesis described in Sect. 3.3. Moreover, even though the sample may contain firms that try to compensate for otherwise weak governance by increasing conservatism (that is, yielding a negative association), this does not seem to be the case for the majority of firms. The fact

\footnotetext{
${ }_{18}$ We also repeated this test including an industry $\times$ year interaction term and obtained the same
} inferences. 
Table 3 Heckman estimation of the impact of governance on a firm-level proxy of conservatism using a levels specification

\begin{tabular}{|c|c|c|c|}
\hline & & \multicolumn{2}{|c|}{ Dependent variable } \\
\hline & & AvgAccr & $A v g A c c r *$ \\
\hline \multirow[t]{2}{*}{ Totgov } & $\alpha$ & 1.01 & -0.51 \\
\hline & $z$-stat & 2.95 & -1.39 \\
\hline \multirow[t]{2}{*}{ LogAssets } & $\beta_{1}$ & -0.16 & -0.05 \\
\hline & $z$-stat & -1.93 & -0.63 \\
\hline \multirow[t]{2}{*}{ StdCFO } & $\beta_{2}$ & -13.96 & 2.29 \\
\hline & $z$-stat & -4.33 & 0.77 \\
\hline \multirow{2}{*}{ StdSales } & $\beta_{3}$ & 2.96 & 0.95 \\
\hline & $z$-stat & 3.59 & 1.01 \\
\hline \multirow[t]{2}{*}{ OperCycle } & $\beta_{4}$ & 1.62 & 0.97 \\
\hline & $z$-stat & 7.26 & 3.96 \\
\hline \multirow[t]{2}{*}{ Int_Intensity } & $\beta_{5}$ & -0.24 & -0.11 \\
\hline & $z$-stat & -1.23 & -0.41 \\
\hline \multirow[t]{2}{*}{ Int_Dummy } & $\beta_{6}$ & 0.67 & 0.08 \\
\hline & $z$-stat & 2.50 & 0.26 \\
\hline \multirow[t]{2}{*}{ Cap_Intensity } & $\beta_{7}$ & -3.72 & -6.27 \\
\hline & $z$-stat & -9.27 & -17.52 \\
\hline \multirow[t]{2}{*}{ Big-5 } & $\beta_{8}$ & 0.47 & 0.56 \\
\hline & $z$-stat & 0.79 & 0.81 \\
\hline Inverse Mills ratio & $z$-stat & 10.37 & -0.49 \\
\hline
\end{tabular}

The sample consists of 6,297 firm-year observations for the years 1992 through 2003. AvgAccr is a firm-level proxy of conservatism. High values of AvgAccr indicate low conservatism. AvgAccr is the three-year average, centered at year $t$, of annual total accruals defined as income before extraordinary items minus cash flow from operations, where both variables are extracted from the statement of cash flows and are deflated by average assets. AvgAccr* is average accruals minus discretionary accruals, estimated using the modified Jones model of Dechow et al. (1995). Totgov is a summary measure of total governance. High (Low) values of Totgov indicate high (low) antitakeover protection and high (low) CEO involvement in board decisions. The control variables are measured as follows: LogAssets is the log of total assets at the beginning of the year. StdCFO is the standard deviation of the firm's rolling 10-year cash flows from operations ending at the beginning of the year. StdSales is the standard deviation of the firm's rolling 10-year sales revenues ending at the beginning of the year. OperCycle is the log of the sum of the firm's days of receivables and days of inventory at the beginning of the year. Int_Intensity is the intangibles intensity measured as the sum of research and development and advertising expenses scaled by sales at the beginning of the year. Int_Dummy is an indicator variable that equals one if Int_Intensity $=0$ and zero otherwise. Cap_Intensity is the ratio of the gross book value of property, plant, and equipment to total assets at the beginning of the year. Big-5 is an indicator variable that equals one if the firm is audited by a top 5 auditor and zero otherwise. The regression also includes two-digit SIC industry and year dummies not reported for parsimony

The (unreported) first stage of the Heckman procedure models governance choice with a dummy variable that indicates whether the firm has selected to have strong or weak governance. Strong (weak) governance denotes that the firm has a total governance score below (above) the median of Totgov. The determinants of governance choice are: size, growth opportunities, firm's age, presence of large free cash flows, idiosyncratic risk, leverage, industry concentration, geographic concentration, CEO tenure, firm's stock performance, whether the firm is audited by a top 5 auditor, and indicator variables for two-digit SIC industry and year dummies

The reported $z$-statistics in italics are based on standard errors which are robust to both heteroscedasticity and within-group serial correlation. The two-sided thresholds of the $z$-statistics for significance at the $0.10,0.05$, and 0.01 confidence levels are $1.64,1.96$, and 2.61 , respectively 
that the results yield a robust positive association between governance and conservatism adds support to the hypothesis that, on average, governance uses conservatism to improve managerial monitoring and control.

\subsection{Does governance influence conservatism or vice versa?}

Bushman et al. (2004) document an inverse association between measures of the informativeness of accounting numbers and governance. In particular, they posit that firms that produce accounting information of limited transparency place a higher burden in governance structures to overcome this shortcoming. They measure the informativeness of accounting numbers using earnings symmetric timeliness, which they define as "the extent to which current accounting earnings incorporate current economic income or value relevant information." They find that earnings symmetric timeliness is negatively associated with current governance level. ${ }^{19}$ However, they are unable to rule out the possibility "that governance structures also influence the properties of accounting numbers through accounting policy choices and earnings management activities" because their test is an association test that is not informative about the direction of the causation. They conclude that their proxy for earnings symmetric timeliness captures a firm characteristic over which management has little discretion.

In our study, we implicitly assume the direction of causation: stronger governance leads to more conservative accounting choices. Our findings in the previous sections document this association. This evidence is necessary, but not sufficient, to infer the direction of causation. In addition, the discretionary accruals results in Sect. 5.1 provide support for the hypothesis that governance influences conservatism by providing a plausible link between the two. Nevertheless, this evidence is insufficient to draw a meaningful conclusion. To overcome this fact and illuminate whether governance influences conservatism or vice versa, we incorpo rate some dynamic features in our tests to obtain more evidence to support our assumption.

Our first test uses changes in governance. We select a sub sample of firms that experience a strengthening in governance from time $t \quad 1$ to time $t$ (that is, $\Delta$ Totgov $<0$ ). Then, for the same set of firms, we run regressions (1) and (3) at time $t \quad 1$ and at time $t$ and compare the change in coefficient $\beta_{3}$. As in previous tests, we use the Heckman procedure. If governance affects accounting conservatism, we would expect to observe an increase in the size of $\beta_{3}$. The left columns of Panel A in Table 4 show the results of this test for the Basu regressions and Panel B for the Ball and Shivakumar accruals regressions. For the Basu regressions, we observe that when governance improves, $\beta_{3}$ increases from 0.04 to 0.08 , and this change is statistically significant $(p$ value $=0.01)$. For the accruals regressions, $\beta_{3}$ increases

19 Notice that our proxies for conservatism-Basu's (1997) earnings asymmetric timeliness, Ball and Shivakumar's (2005) accruals asymmetric timeliness, and Givoly and Hayn's (2000) average accrualsare different from the measure for the relevance of accounting numbers used by Bushman et al. Their measure captures earnings symmetric timeliness, which is closer to what the literature refers to as relevance. 
from 0.09 to 0.21 , and this change is also statistically significant ( $p$ value $=0.1$ ). In the right columns of Table 4, we perform the same tests but use a sub sample of firms that experience a weakening in governance from $t \quad 1$ to time $t$ (that is, $\Delta$ Totgov $>0$ ). For the Basu regressions, the change in $\beta_{3}$ is not significantly different from zero ( $p$ value $=0.33$ ). This result is unexpected and does not allow us to draw any inference on the direction of causation. The firms in the sub sample with negative changes in Totgov may have "excess" governance and may simply be adjusting their governance structures towards the required level without changing

Table 4 Heckman estimation of the change in conservatism when governance changes. Panel A contains the Heckman estimation of the Basu (1997) regression equation at time $t \quad l$ and at time $t$, when governance improves $(\Delta$ Totgov $<0)$ and when governance worsens $(\Delta$ Totgov $>0)$. Panel B contains the Heckman estimation of the accruals regression of Ball and Shivakumar (2005) at time $t \quad 1$ and at time $t$, when governance improves $(\Delta$ Totgov $<0)$ and when governance worsens $(\Delta$ Totgov $>0)$

Panel A: Basu (1997) regressions: $X_{j}=\beta_{0}+\beta_{1} D_{j}+\beta_{2} R_{j}+\beta_{3} D_{j} R_{j}+\mu_{j}$

\begin{tabular}{|c|c|c|c|c|c|}
\hline & & \multicolumn{4}{|c|}{ Dependent variable: $X_{j}$} \\
\hline & & \multicolumn{2}{|c|}{$\begin{array}{l}\text { Improvement in governance: } \\
\Delta \text { Totgov }<0\end{array}$} & \multicolumn{2}{|c|}{$\begin{array}{l}\text { Worsening in governance: } \\
\Delta \text { Totgov }>0\end{array}$} \\
\hline & & $j=t \quad l$ & $j=t$ & $j=t \quad 1$ & $j=t$ \\
\hline \multirow[t]{2}{*}{ Constant } & $\beta_{0}$ & 0.01 & 0.02 & 0.03 & 0.01 \\
\hline & $z$-stat & 1.06 & 1.80 & 4.39 & 0.57 \\
\hline \multirow[t]{2}{*}{$D_{j}$} & $\beta_{1}$ & 0.00 & 0.01 & 0.01 & 0.00 \\
\hline & $z$-stat & 0.72 & 3.09 & 1.81 & 0.17 \\
\hline \multirow[t]{2}{*}{ Return $_{j}$} & $\beta_{2}$ & 0.02 & 0.02 & 0.02 & 0.02 \\
\hline & $z$-stat & 3.91 & 2.86 & 2.40 & 2.20 \\
\hline \multirow[t]{2}{*}{$D_{j} \times$ Return $_{j}$} & $\beta_{3}$ & 0.04 & 0.08 & 0.08 & 0.08 \\
\hline & $z$-stat & 4.12 & 7.18 & 6.70 & 7.01 \\
\hline Inverse Mills ratio & $z$-stat & 6.45 & 4.76 & 3.65 & 4.83 \\
\hline \multicolumn{2}{|c|}{$p$-Value of difference in $\beta_{3}$} & 0.01 & & 0.33 & \\
\hline \multicolumn{2}{|l|}{ N. obs. } & 3,452 & & 3,211 & \\
\hline
\end{tabular}

Panel B: Accruals regressions: $A c c r_{j}=\beta_{0}+\beta_{1} D C F O_{j}+\beta_{2} C F O_{j}+\beta_{3} D C F O_{j} \mathrm{CFO}_{j}+\mu_{j}$

\begin{tabular}{|c|c|c|c|c|c|}
\hline & & \multicolumn{4}{|c|}{ Dependent variable: $A c c r_{j}$} \\
\hline & & \multicolumn{2}{|c|}{$\begin{array}{l}\text { Improvement in governance: } \\
\Delta \text { Totgov }<0\end{array}$} & \multicolumn{2}{|c|}{$\begin{array}{l}\text { Worsening in governance: } \\
\Delta \text { Totgov }>0\end{array}$} \\
\hline & & $j=t \quad 1$ & $j=t$ & $j=t \quad 1$ & $j=t$ \\
\hline \multirow[t]{2}{*}{ Constant } & $\beta_{0}$ & 0.03 & 0.03 & 0.02 & 0.01 \\
\hline & $z$-stat & 3.80 & 5.21 & 4.25 & 4.00 \\
\hline \multirow[t]{2}{*}{$D_{C F O}$} & $\beta_{1}$ & 0.01 & 0.01 & 0.01 & 0.01 \\
\hline & $z$-stat & 2.87 & 2.44 & 2.41 & 2.56 \\
\hline \multirow[t]{2}{*}{$C F O_{j}$} & $\beta_{2}$ & 0.35 & 0.37 & 0.41 & 0.38 \\
\hline & z-stat & 8.75 & 8.95 & 10.42 & 12.25 \\
\hline
\end{tabular}


Table 4 continued

Panel B: Accruals regressions: $A c c r_{j}=\beta_{0}+\beta_{1} D C F O_{j}+\beta_{2} C F O_{j}+\beta_{3} D C F O_{j} \mathrm{CFO}_{j}+\mu_{j}$

\begin{tabular}{|c|c|c|c|c|c|}
\hline & & \multicolumn{4}{|c|}{ Dependent variable: $A c c r_{j}$} \\
\hline & & \multicolumn{2}{|c|}{$\begin{array}{l}\text { Improvement in } \\
\text { governance: } \Delta \text { Totgov }<0\end{array}$} & \multicolumn{2}{|c|}{$\begin{array}{l}\text { Worsening in governance: } \\
\Delta \text { Totgov }>0\end{array}$} \\
\hline & & $j=t \quad l$ & $j=t$ & $j=t \quad 1$ & $j=t$ \\
\hline \multirow[t]{2}{*}{$\mathrm{DCFO}_{j} \times C F O_{j}$} & $\beta_{3}$ & 0.09 & 0.21 & 0.17 & 0.04 \\
\hline & $z$-stat & 1.46 & 3.43 & 2.67 & 0.79 \\
\hline Inverse Mills ratio & $z$-stat & 3.85 & 6.03 & 4.70 & 4.90 \\
\hline \multicolumn{2}{|c|}{$p$-Value of difference in $\beta_{3}$} & \multicolumn{2}{|l|}{0.10} & \multicolumn{2}{|l|}{0.05} \\
\hline \multicolumn{2}{|l|}{ N. obs. } & \multicolumn{2}{|l|}{3,452} & \multicolumn{2}{|l|}{3,211} \\
\hline
\end{tabular}

The complete sample consists of 9,152 firm-year observations (1,611 firms) for the years 1992 through 2003. In Panel A, $X$ is earnings per share before extraordinary items and discontinued operations deflated by share price at the beginning of the period. $R$ is the annual stock return measured as the continuously compounded monthly CRSP return over the firm's fiscal year. $D$ is a dummy variable that equals one in the case of bad news (negative or zero of market-adjusted stock rate of return); zero otherwise. In Panel B, Accr denotes industry-adjusted annual total accruals, deflated by average assets, defined as income before extraordinary items minus cash flow from operations, where both variables are extracted from the statement of cash flows. $C F O$ is industry-adjusted cash flow from operations taken from the statement of cash flows, deflated by average assets. $D C F O$ is a dummy variable equal to one in the case of negative CFO and zero otherwise. In both Panels, Totgov is a summary measure of total governance. High (Low) values of Totgov indicate high (low) antitakeover protection and high (low) CEO involvement in board decisions. The (unreported) first stage of the Heckman procedure models governance choice with a dummy variable that indicates whether the firm has selected to have strong or weak governance. Strong (weak) governance denotes that the firm has a total governance score below (above) the median of Totgov. The determinants of governance choice are size, growth opportunities, firm's age, presence of large free cash flows, idiosyncratic risk, leverage, industry concentration, geographic concentration, CEO tenure, firm's stock performance, whether the firm is in a regulated industry, whether the firm is in a high technology-industry, whether the firm is audited by a top Big Five auditor, and indicator variables for the fiscal year

The reported $z$-statistics in italics are based on standard errors which are robust to both heteroscedasticity and within-group serial correlation. The two-sided thresholds of the $z$-statistics for significance at the $0.10,0.05$, and 0.01 confidence levels are $1.64,1.96$, and 2.61 , respectively

the level of conservatism. However, when we repeat this test for the accruals regressions in Panel $\mathrm{B}$, we see that as governance worsens, $\beta_{3}$ decreases from 0.17 to 0.04 , and this change is statistically significant $(p$ value $=0.05)$. Overall, these results are consistent with the hypotheses that governance influences conservatism and that the association between both is positive.

The structure of the Basu (1997) and Ball and Shivakumar (2005) regressions makes it difficult to test for governance effects when conservatism changes because these approaches do not estimate a firm level proxy of conservatism. Fortunately, the Givoly and Hayn average accruals proxy of conservatism does allow for this type of analysis providing firm year measures of conservatism. We provide further evidence on the issue of causation by running the following regressions, which are identical except for the fact that we swap the dependent variable: 


$$
\begin{aligned}
& \text { AvgAccr }_{t}=\alpha_{1} \text { Totgov }_{t-1}+\alpha_{2} \text { Totgov }_{t-2}+\alpha_{3} \text { Totgov }_{t-3}+\alpha_{4} \text { AvgAccr }_{t-1} \\
& +\alpha_{5} A v \text { gAccr }_{t-2}+\alpha_{6} \text { AvgAccr } r_{t-3}+\beta \text { Controls }_{t-1}+\gamma \text { Industry dummies } \\
& +\delta \text { Year dummies }+\mu_{t}
\end{aligned}
$$

$$
\begin{aligned}
\text { Totgov }_{t}= & \alpha_{1} \text { Totgov }_{t-1}+\alpha_{2} \text { Totgov }_{t-2}+\alpha_{3} \text { Totgov }_{t-3}+\alpha_{4} \text { AvgAccr }_{t-1} \\
& +\alpha_{5} \text { AvgAccr } \\
& +\delta \text { Year dummies }+\alpha_{t} \text { AvgAcr }_{t-3}+\beta \text { Control }_{t-1}+\gamma \text { Industry dummies }
\end{aligned}
$$

This test is in the spirit of Granger (1969) and Sims (1972). We first estimate regression (6) using the Heckman procedure and assess the joint significance of coefficients $\alpha_{1}, \alpha_{2}$, and $\alpha_{3}$. Table 5 shows that the $p$ value of $\alpha_{1}=0, \alpha_{2}=0, \alpha_{3}=0$ equals 0.07 , and the $p$ value of $\alpha_{1}+\alpha_{2}+\alpha_{3}=0$ equals 0.04 . This provides initial evidence that governance causes conservatism in a Granger sense. Then we estimate regression (7) and test the joint significance of $\alpha_{4}, \alpha_{5}$, and $\alpha_{6}$. The $p$ value of $\alpha_{4}=0$, $\alpha_{5}=0, \alpha_{6}=0$ equals 0.36 , and the $p$ value of $\alpha_{4}+\alpha_{5}+\alpha_{6}=0$ equals 0.88 . This evidence indicates that conservatism does not cause governance in a Granger sense.

\begin{tabular}{|c|c|c|c|}
\hline & & \multicolumn{2}{|c|}{ Dependent variable } \\
\hline & & $A v g A c c r_{t}$ & Totgov $_{t}$ \\
\hline \multirow[t]{2}{*}{ Totgov $_{t} 1$} & $\alpha_{1}$ & 1.02 & 0.73 \\
\hline & $z$-stat & 2.47 & 23.94 \\
\hline \multirow[t]{2}{*}{ Totgov $_{t} 2$} & $\alpha_{2}$ & 0.20 & 0.04 \\
\hline & $z$-stat & 0.53 & 1.38 \\
\hline \multirow[t]{2}{*}{ Totgov $_{t} 3$} & $\alpha_{3}$ & 0.17 & 0.11 \\
\hline & $z$-stat & 0.54 & 4.60 \\
\hline \multirow[t]{2}{*}{$A v g A c c r_{t} \quad l$} & $\alpha_{4}$ & 0.61 & 0.00 \\
\hline & $z$-stat & 27.39 & 1.22 \\
\hline \multirow[t]{2}{*}{$A v g A_{c c r}{ }_{t}$} & $\alpha_{5}$ & 0.23 & 0.00 \\
\hline & $z$-stat & 9.26 & 1.72 \\
\hline \multirow[t]{2}{*}{$A v g A c c r_{t} 3$} & $\alpha_{6}$ & 0.16 & 0.00 \\
\hline & $z$-stat & 7.42 & 0.62 \\
\hline \multirow[t]{2}{*}{ LogAssets } & $\beta_{1}$ & 0.05 & 0.01 \\
\hline & $z$-stat & 0.59 & 2.68 \\
\hline \multirow[t]{2}{*}{ StdCFO } & $\beta_{2}$ & 6.51 & 0.31 \\
\hline & z-stat & 2.61 & 1.71 \\
\hline
\end{tabular}
Taking together the results of both tests, we can conclude that the evidence is consistent with governance causing conservatism in a Granger sense and not vice versa.

Table 5 Heckman estimation of the impact of governance on a firm-level proxy of conservatism using a levels specification 
Table 5 continued

\begin{tabular}{|c|c|c|c|}
\hline & & \multicolumn{2}{|c|}{ Dependent variable } \\
\hline & & $A v g A c c r_{t}$ & Totgov $_{t}$ \\
\hline \multirow[t]{2}{*}{ StdSales } & $\beta_{3}$ & 0.93 & 0.31 \\
\hline & $z$-stat & 1.22 & 1.52 \\
\hline \multirow[t]{2}{*}{ OperCycle } & $\beta_{4}$ & 0.30 & 0.00 \\
\hline & $z$-stat & 1.44 & 0.00 \\
\hline \multirow[t]{2}{*}{ Int Intensity } & $\beta_{5}$ & 0.01 & 0.01 \\
\hline & $z$-stat & 0.04 & 0.84 \\
\hline \multirow[t]{2}{*}{ Int Dummy } & $\beta_{6}$ & 0.49 & 0.01 \\
\hline & $z$-stat & 1.87 & 0.30 \\
\hline \multirow[t]{2}{*}{ Cap Intensity } & $\beta_{7}$ & 1.15 & 0.01 \\
\hline & $z$-stat & 3.56 & 0.42 \\
\hline \multirow[t]{2}{*}{ Big-5 } & $\beta_{8}$ & 0.27 & 0.04 \\
\hline & $z$-stat & 0.38 & 0.74 \\
\hline Inverse Mills ratio & $z$-stat & 4.06 & 2.59 \\
\hline$p$-Value $\alpha_{1}=0, \alpha_{2}=0, \alpha_{3}=0$ & & 0.07 & \\
\hline$p$-Value $\alpha_{1}+\alpha_{2}+\alpha_{3}=0$ & & 0.04 & \\
\hline$p$-Value $\alpha_{4}=0, \alpha_{5}=0, \alpha_{6}=0$ & & & 0.36 \\
\hline$p$-Value $\alpha_{4}+\alpha_{5}+\alpha_{6}=0$ & & & 0.88 \\
\hline
\end{tabular}

The sample consists of 5,764 firm-year observations for the years 1992 through 2003. AvgAccr is a firmlevel proxy of conservatism. High values of AvgAccr indicate low conservatism. AvgAccr is the threeyear average, centered at year $t$, of annual total accruals defined as income before extraordinary items minus cash flow from operations, where both variables are extracted from the statement of cash flows and are deflated by average assets. AvgAccr* is average accruals minus discretionary accruals, estimated using the modified Jones model of Dechow et al. (1995). Totgov is a summary measure of total governance. High (Low) values of Totgov indicate high (low) antitakeover protection and high (low) CEO involvement in board decisions. The control variables are measured as follows: LogAssets is the log of total assets at the beginning of the year. StdCFO is the standard deviation of the firm's rolling 10-year cash flows from operations ending at the beginning of the year. StdSales is the standard deviation of the firm's rolling 10-year sales revenues ending at the beginning of the year. OperCycle is the log of the sum of the firm's days of receivables and days of inventory at the beginning of the year. Int Intensity is the intangibles intensity measured as the sum of research and development and advertising expenses scaled by sales at the beginning of the year. Int Dummy is an indicator variable that equals one if Int Intensity $=0$ and zero otherwise. Cap Intensity is the ratio of the gross book value of property, plant, and equipment to total assets at the beginning of the year. Big-5 is an indicator variable that equals one if the firm is audited by a Big Five auditor and zero otherwise. The regression also includes two-digit SIC industry and year dummies not reported for parsimony

The (unreported) first stage of the Heckman procedure models governance choice with a dummy variable that indicates whether the firm has selected to have strong or weak governance. Strong (weak) governance denotes that the firm has a total governance score below (above) the median of Totgov. The determinants of governance choice are size, growth opportunities, firm's age, presence of large free cash flows, idiosyncratic risk, leverage, industry concentration, geographic concentration, CEO tenure, firm's stock performance, whether the firm is audited by a top 5 auditor, and indicator variables for two-digit SIC industry and year dummies

The reported $z$-statistics in italics are based on standard errors which are robust to both heteroscedasticity and within-group serial correlation. The two-sided thresholds of the $z$-statistics for significance at the $0.10,0.05$, and 0.01 confidence levels are $1.64,1.96$, and 2.61 , respectively 
Regressions (6) and (7) are based on levels of governance and conservatism. This type of regression is more likely to be affected by omitted correlated variables and, because the dependent variables are averaged over three years, they may suffer from serial dependency problems, which may bias the inferences. To assess the impact of this possibility, we repeat the tests using changes as follows:

$$
\begin{aligned}
& \Delta \text { AvgAccr }_{t}=\alpha_{1} \Delta \text { Totgov }_{t-1}+\alpha_{2} \Delta \text { Totgov }_{t-2}+\alpha_{3} \Delta \text { AvgAccr }_{t-1}+\alpha_{4} \Delta \text { AvgAccr }_{t-2} \\
& +\beta \text { Controls }_{t-1}+\gamma \text { Industry dummies }+\delta \text { Year dummies }+\mu_{t}
\end{aligned}
$$

$$
\begin{aligned}
& \Delta \text { Totgov }_{t}=\alpha_{1} \Delta \text { Totgov }_{t-1}+\alpha_{2} \Delta \text { Totgov }_{t-2}+\alpha_{3} \Delta A v \text { gAcr }_{t-1}+\alpha_{4} \Delta A v g A c c r_{t-2} \\
& +\beta \text { Controls }_{t-1}+\gamma \text { Industry dummies }+\delta \text { Year dummies }+\mu_{t}
\end{aligned}
$$

The results of the Heckman estimation of these two equations are presented in Table 6 and confirm the inferences drawn above and in the initial tests of Table 4: all the empirical evidence reported in this section is strongly consistent with governance causing conservatism in a Granger sense and not vice versa.

The findings on this section also rule out an alternative explanation for the positive association between governance and conservatism. CEOs of firms that exhibit good performance because of the use of aggressive accounting practices (that is, low conservatism) may be able to gain substantial bargaining power with

\begin{tabular}{|c|c|c|c|}
\hline & & \multicolumn{2}{|c|}{ Dependent variable } \\
\hline & & $\Delta A v g A c c r_{t}$ & $\Delta$ Totgov $_{t}$ \\
\hline \multirow[t]{2}{*}{$\Delta$ Totgov $_{t}{ }_{l}$} & $\alpha_{1}$ & 1.02 & 0.17 \\
\hline & $z$-stat & 2.79 & 6.98 \\
\hline \multirow[t]{2}{*}{$\Delta$ Totgov $_{t} 2$} & $\alpha_{2}$ & 0.52 & 0.13 \\
\hline & $z$-stat & 1.52 & 5.61 \\
\hline \multirow[t]{2}{*}{$\triangle A v g A c c r_{t}$} & $\alpha_{3}$ & 0.17 & 0.00 \\
\hline & $z$-stat & 7.92 & 1.31 \\
\hline \multirow[t]{2}{*}{$\Delta A v g A c c r_{t} 2$} & $\alpha_{4}$ & 0.35 & 0.00 \\
\hline & $z$-stat & 16.80 & 0.89 \\
\hline \multirow[t]{2}{*}{ LogAssets } & $\beta_{1}$ & 0.04 & 0.01 \\
\hline & $z$-stat & 0.51 & 1.83 \\
\hline \multirow[t]{2}{*}{ StdCFO } & $\beta_{2}$ & 2.59 & 0.43 \\
\hline & $z$-stat & 0.96 & 2.38 \\
\hline \multirow[t]{2}{*}{ StdSales } & $\beta_{3}$ & 0.04 & 0.07 \\
\hline & $z$-stat & 0.05 & 1.24 \\
\hline \multirow[t]{2}{*}{ OperCycle } & $\beta_{4}$ & 0.67 & 0.00 \\
\hline & $z$-stat & 3.00 & 0.30 \\
\hline
\end{tabular}
the board and exert significant influence in governance decisions (that is, weak

Table 6 Heckman estimation of the impact of governance on a firm-level proxy of conservatism using a changes specification 
Table 6 continued

\begin{tabular}{lllc}
\hline & & \multicolumn{2}{l}{ Dependent variable } \\
\cline { 4 - 4 } & & $\Delta$ AvgAccr & \\
\hline Int Intensity & $\beta_{5}$ & 0.18 & $\Delta$ Totgov $_{t}$ \\
Int Dummy & $z$-stat & 0.89 & 0.01 \\
& $\beta_{6}$ & 0.27 & 1.01 \\
Cap Intensity & $z$-stat & 0.91 & 0.01 \\
& $\beta_{7}$ & 0.91 & 0.48 \\
Big-5 & $z$-stat & 2.73 & 0.00 \\
& $\beta_{8}$ & 0.32 & 0.18 \\
Inverse Mills ratio & $z$-stat & 0.41 & 0.02 \\
$p$-Value $\alpha_{1}=0, \alpha_{2}=0$ & $z$-stat & 3.04 & 0.42 \\
$p$-Value $\alpha_{1}+\alpha_{2}=0$ & & 0.02 & 2.03 \\
$p$-Value $\alpha_{3}=0, \alpha_{4}=0$ & & 0.01 & \\
$p$-Value $\alpha_{3}+\alpha_{4}=0$ & & & 0.24 \\
\hline
\end{tabular}

The sample consists of 5,764 firm-year observations for the years 1992 through 2003. AvgAccr is a firmlevel proxy of conservatism. High values of AvgAccr indicate low conservatism. AvgAccr is the threeyear average, centered at year $t$, of annual total accruals defined as income before extraordinary items minus cash flow from operations, where both variables are extracted from the statement of cash flows and are deflated by average assets. AvgAccr* is average accruals minus discretionary accruals, estimated using the modified Jones model of Dechow et al. (1995). Totgov is a summary measure of total governance. High (Low) values of Totgov indicate high (low) antitakeover protection and high (low) CEO involvement in board decisions. The control variables are measured as follows: LogAssets is the log of total assets at the beginning of the year. StdCFO is the standard deviation of the firm's rolling 10-year cash flows from operations ending at the beginning of the year. StdSales is the standard deviation of the firm's rolling 10-year sales revenues ending at the beginning of the year. OperCycle is the log of the sum of the firm's days of receivables and days of inventory at the beginning of the year. Int Intensity is the intangibles intensity measured as the sum of research and development and advertising expenses scaled by sales at the beginning of the year. Int Dummy is an indicator variable that equals one if Int Intensity $=0$ and zero otherwise. Cap Intensity is the ratio of the gross book value of property, plant, and equipment to total assets at the beginning of the year. Big-5 is an indicator variable that equals one if the firm is audited by a Big Five auditor, and zero otherwise. The regression also includes two-digit SIC industry and year dummies not reported for parsimony

The (unreported) first stage of the Heckman procedure models governance choice with a dummy variable that indicates whether the firm has selected to have strong or weak governance. Strong (weak) governance denotes that the firm has a total governance score below (above) the median of Totgov. The determinants of governance choice are size, growth opportunities, firm's age, presence of large free cash flows, idiosyncratic risk, leverage, industry concentration, geographic concentration, CEO tenure, firm's stock performance, whether the firm is audited by a top 5 auditor, and indicator variables for two-digit SIC industry and year dummies

The reported $z$-statistics in italics are based on standard errors which are robust to both heteroscedasticity and within-group serial correlation. The two-sided thresholds of the $z$-statistics for significance at the $0.10,0.05$, and 0.01 confidence levels are $1.64,1.96$, and 2.61 , respectively

governance). This would be consistent with the documented positive association between conservatism and governance and with conservatism influencing gover nance. However, the results of the previous tests reject this possibility. 
A final comment seems in order. Our findings should not be interpreted as contradicting the findings of Bushman et al. (2004). On the contrary, we interpret our results as complementary. First, they do not measure accounting conservatism but accounting relevance. And second, firms with noisier accounting environments beyond the control of management may call for enhanced governance structures and, as a result of such enhancements, the strengthening in governance leads to increases in accounting conservatism.

\subsection{Impact on conditional conservatism of an exogenous shock to governance}

Despite all the evidence presented so far, our tests may still suffer from endogeneity bias. As a final test, we try to isolate a situation in which an external shock to governance has occurred. If we found such an instance, studying what happens to conditional conservatism before and after the shock could confirm our previous findings. Fortunately, the passage by U.S. legislators of the Sarbanes Oxley Act of 2002 (SOX) provides the perfect setting for this test. The spate of accounting scandals of the early 2000s (Enron, WorldCom, Adelphia, etc.) led to the passage of SOX. Its main purpose was to "protect investors by improving the accuracy and reliability of corporate disclosures and to restore investors' confidence in the integrity of firms' financial reporting" (Lobo and Zhou 2006). To achieve this purpose, SOX requires CEOs and CFOs of listed companies to certify the "material accuracy and completeness of financial statements." SOX imposes stringent criminal penalties to corporate officials who knowingly certify financial statements that do not meet its requirements. These new provisions imply an increase in the level of corporate governance brought about by factors exogenous to the firm. Lobo and Zhou (2006) investigate the impact of SOX on accounting conservatism and document an increase in conditional conservatism following SOX. Their evidence is consistent with our results.

We use Eqs. 1 and 3 to test whether the passage of SOX has an impact on the conservatism policies of our sample firms. We isolate a sub sample of firms that are present in the pre and post SOX periods: that is, years 2001 and 2003. Then we estimate the Basu and the Ball and Shivakumar regressions and examine whether there is a significant increase in the coefficient that captures conservatism, $\beta_{3}$. Untabulated results indicate that the average level of governance (as measured by Totgov) increased by almost 50\% from 2001 to 2003. Table 7 contains the results. For the Basu regression, $\beta_{3}$ increases from 0.08 to 0.14 , and the $p$ value of this difference equals 0.04 . For the accruals regressions, $\beta_{3}$ increases from 0.10 to 0.25 , and the $p$ value of this difference equals 0.08 . This evidence reproduces Lobo and Zhou's (2006) findings and provides more support to all our previous results and our prediction of causality: stronger governance monitoring results in an increase in conditional conservatism. 
Table 7 Estimation of the change in asymmetric timeliness after the Sarbanes-Oxley Act of 2002. Estimation of the Basu (1997) and the Ball and Shivakumar (2005) regression equations, before (year 2001) and after (year 2003) the passage of the Sarbanes-Oxley Act of 2002. Coefficient $\beta_{3}$ captures the level of asymmetric timeliness

\begin{tabular}{|c|c|c|c|c|c|c|c|}
\hline \multirow[t]{2}{*}{ Panel A } & & \multicolumn{2}{|c|}{ Dependent variable: $X$} & \multirow{2}{*}{\multicolumn{2}{|c|}{ Panel B }} & \multicolumn{2}{|c|}{ Dependent variable: $A c c r$} \\
\hline & & $\begin{array}{l}\text { Pre-SOX } \\
\text { year } 2001\end{array}$ & $\begin{array}{l}\text { Post-SOX } \\
\text { year } 2003\end{array}$ & & & $\begin{array}{l}\text { Pre-SOX } \\
\text { year } 2001\end{array}$ & $\begin{array}{l}\text { Post-SOX } \\
\text { year } 2003\end{array}$ \\
\hline \multirow[t]{2}{*}{ Constant } & $\beta_{0}$ & 0.04 & 0.05 & Constant & $\beta_{0}$ & 0.01 & 0.01 \\
\hline & $t$-stat & 9.74 & 7.23 & & t-stat & 1.79 & 2.49 \\
\hline \multirow[t]{2}{*}{$D$} & $\beta_{1}$ & 0.00 & 0.03 & $D C F O$ & $\beta_{1}$ & 0.00 & 0.00 \\
\hline & $t$-stat & 0.33 & 3.14 & & t-stat & 0.62 & 0.11 \\
\hline \multirow[t]{2}{*}{ Return } & $\beta_{2}$ & 0.02 & 0.01 & $C F O$ & $\beta_{2}$ & 0.46 & 0.43 \\
\hline & $t$-stat & 1.00 & 0.61 & & $t$-stat & 9.25 & 9.01 \\
\hline \multirow[t]{2}{*}{$D \times$ Return } & $\beta_{3}$ & 0.08 & 0.14 & $D C F O \times C F O$ & $\beta_{3}$ & 0.10 & 0.25 \\
\hline & $t$-stat & 3.09 & 4.56 & & $t$-stat & 1.19 & 3.54 \\
\hline$R^{2}$ & & 0.07 & 0.06 & $R^{2}$ & & 0.28 & 0.20 \\
\hline \multicolumn{2}{|c|}{$p$-Value difference in $\beta_{3}$} & \multicolumn{2}{|l|}{0.04} & \multicolumn{2}{|c|}{$p$-Value difference in $\beta_{3}$} & 0.08 & \\
\hline
\end{tabular}

The sample consists of 743 firms that are present in the sample in the years 2001 through 2003. In Panel A, $X$ is earnings per share before extraordinary items and discontinued operations deflated by share price at the beginning of the period. $R$ is the annual stock return measured as the continuously compounded monthly CRSP return over the firm's fiscal year. $D$ is a dummy variable that equals one in the case of bad news (negative or zero market-adjusted stock rate of return); zero otherwise. In Panel B, Accr denotes industry-adjusted annual total accruals, deflated by average assets, defined as income before extraordinary items minus cash flow from operations, where both variables are extracted from the statement of cash flows. $C F O$ is industry-adjusted cash flow from operations taken from the statement of cash flows, deflated by average assets. $D C F O$ is a dummy variable equal to one in the case of negative $C F O$ and zero otherwise

The reported $t$-statistics in italics are based on robust standard errors. The two-sided thresholds of the $t$ statistics for significance at the $0.10,0.05$, and 0.01 confidence levels are 1.64, 1.96, and 2.61, respectively

\subsection{Analysis of the market to book effects on the level of conditional conservatism}

Roychowdhury and Watts (2006) show that it is important to control for the investment opportunity set when estimating the level of asymmetric timeliness because variation in growth opportunities can create variation in the estimates of asymmetric timeliness that is unrelated to conservatism. We use the level of the market to book ratio $(M T B)$ as a proxy for the investment opportunity set. The $M T B$ also acts as a proxy for unconditional conservatism. As detailed in Beaver and Ryan (2005), unconditional and conditional conservatism are inherently linked, higher unconditional conservatism likely driving the estimates of conditional conservatism down. To ensure that our results are not driven by differences in the investment opportunity set or the level of unconditional conservatism, we repeat all the tests in Table 2, controlling for differences in the $M T B$ ratio. Following Roychowdhury and Watts (2006), to perform this test, we introduce $M T B$ into Eqs. 1 and 3 in the following fashion: 


$$
\begin{aligned}
X_{t}= & \beta_{0}+\beta_{1} D_{t}+\beta_{2} M_{T B}+\beta_{3} R_{t}+\beta_{4} D_{t} M_{t} B_{t}+\beta_{5} R_{t} M T B_{t}+\beta_{6} D_{t} R_{t} \\
& +\beta_{7} D_{t} R_{t} M T B_{t}+\mu_{t} \\
\text { Accr }_{t}= & \beta_{0}+\beta_{1} \text { DCFO }_{t}+\beta_{2} \text { MTB }_{t}+\beta_{3} \text { CFO }_{t}+\beta_{4} \text { DCFO }_{t} M_{T B}+\beta_{5} \text { CFO }_{t} M T B_{t} \\
& +\beta_{6} \text { DCFO }_{t} \text { CFO }_{t}+\beta_{7} \text { DCFO }_{t} \text { CFO }_{t} M T B_{t}+\mu_{t}
\end{aligned}
$$

Table 8 shows the estimation results of both equations across governance structures when the sample is partitioned into strong and weak governance firms at the median of Totgov. ${ }^{20}$ Even after controlling for $M T B$, strong governance firms exhibit more accounting conservatism than weak firms do. The first two columns of Panel A indicate that the difference in the asymmetric timeliness coefficients $\beta_{6}$ across governance structures is still significant at conventional levels ( $p$ value $=0.00$ ), whereas the difference in $\beta_{7}$, the coefficient that captures the influence of $M T B$ differences on asymmetric timeliness, is not significantly different from zero $(p$ value $=0.14$ ). Consistent with the results of Roychowdh ury and Watts (2006), $\beta_{7}$ is negatively significant but only for strong governance firms. The same result is obtained when we estimate in Panel B Eq. 11: the difference in the asymmetric timeliness coefficients $\beta_{6}$ across governance structures is still significant at conventional levels ( $p$ value $=0.02)$, whereas the difference in $\beta_{7}$, the coefficient that captures the influence of investment opportunities and unconditional conservatism on asymmetric timeliness, is not significantly different from zero $(p$ value $=0.33$ ). Overall, the findings in Table 8 confirm that the observed differences in conservatism across governance structures depicted in Tables 2 and 3 are not driven by differences in the $M T B$ ratio.

\section{Conclusions}

In this paper, we assess the association between corporate governance and conditional accounting conservatism. In particular, we investigate whether firms with strong corporate governance exhibit a higher degree of accounting conserva tism than firms with weak governance. We measure conservatism using three proxies. The first one is market based and the other two are accruals based. In our tests, we control for the endogenous nature of corporate governance and the fact that governance and conservatism may be simultaneously determined.

We estimate the level of corporate governance using a composite measure that incorporates the level of antitakeover protection and the level of CEO involvement

\footnotetext{
${ }^{20}$ In these tests we are unable to use the Heckman procedure as described in Sect. 3.3. The reason is that here we are partitioning the sample into strong and weak governance firms, and the probit regression that models governance choice cannot be applied to each partition separately. Nevertheless, all previous evidence indicates that the results are not biased by not taking into account the endogeneity of governance choice.
} 
Table 8 Estimation of the differences in asymmetric timeliness across governance structures after controlling for the investment opportunity set. The table contains the pooled estimation of the Basu (1997) and Ball and Shivakumar (2005) regressions, interacted with a proxy for the investment opportunity set $(M T B)$. The sample has been divided in two groups according to the level of total governance, Totgov. High (Low) values of Totgov indicate high (low) antitakeover protection and high (low) CEO involvement in board decisions. Observations below (above) the median of Totgov are referred to as strong (weak) governance firms: those with low (high) antitakeover protection and low (high) CEO involvement in board decisions

\begin{tabular}{|c|c|c|c|c|c|c|c|}
\hline \multirow[t]{2}{*}{ Panel A } & & \multicolumn{2}{|c|}{ Dependent variable: $X$} & \multirow{2}{*}{\multicolumn{2}{|c|}{ Panel B }} & \multicolumn{2}{|c|}{ Dependent variable: $A c c r$} \\
\hline & & $\begin{array}{l}\text { Strong } \\
\text { Gov. }\end{array}$ & $\begin{array}{l}\text { Weak } \\
\text { Gov. }\end{array}$ & & & $\begin{array}{l}\text { Strong } \\
\text { Gov. }\end{array}$ & $\begin{array}{l}\text { Weak } \\
\text { Gov. }\end{array}$ \\
\hline \multirow[t]{2}{*}{ Constant } & $\beta_{0}$ & 0.04 & 0.05 & Constant & $\beta_{0}$ & 0.00 & 0.00 \\
\hline & t-stat & 17.50 & 26.22 & & $t$-stat & 1.79 & 0.55 \\
\hline \multirow[t]{2}{*}{$D$} & $\beta_{1}$ & 0.01 & 0.00 & $D C F O$ & $\beta_{1}$ & 0.01 & 0.01 \\
\hline & $t$-stat & 1.81 & 1.86 & & $t$-stat & 4.99 & 3.77 \\
\hline \multirow[t]{2}{*}{$M T B$} & $\beta_{2}$ & 0.00 & 0.00 & $M T B$ & $\beta_{2}$ & 0.00 & 0.00 \\
\hline & $t$-stat & 1.38 & 2.53 & & $t$-stat & 2.74 & 1.34 \\
\hline \multirow[t]{2}{*}{ Return } & $\beta_{3}$ & 0.00 & 0.02 & $\mathrm{CFO}$ & $\beta_{3}$ & 0.45 & 0.43 \\
\hline & t-stat & 0.90 & 4.83 & & $t$-stat & 11.97 & 10.05 \\
\hline \multirow[t]{2}{*}{$D \times M T B$} & $\beta_{4}$ & 0.00 & 0.00 & $D C F O \times M T B$ & $\beta_{4}$ & 0.00 & 0.00 \\
\hline & t-stat & 2.31 & 0.78 & & $t$-stat & 2.54 & 0.97 \\
\hline \multirow[t]{2}{*}{ Return $\times M T B$} & $\beta_{5}$ & 0.00 & 0.00 & $C F O \times M T B$ & $\beta_{5}$ & 0.00 & 0.01 \\
\hline & t-stat & 0.09 & 0.39 & & $t$-stat & 0.79 & 1.12 \\
\hline \multirow[t]{2}{*}{$D \times$ Return } & $\beta_{6}$ & 0.12 & 0.08 & $D C F O \times C F O$ & $\beta_{6}$ & 0.33 & 0.15 \\
\hline & t-stat & 12.34 & 8.27 & & $t$-stat & 6.26 & 2.34 \\
\hline \multirow[t]{2}{*}{$D \times$ Return $\times M T B$} & $\beta_{7}$ & 0.00 & 0.00 & $D C F O \times C F O$ & $\beta_{7}$ & 0.00 & 0.01 \\
\hline & t-stat & 2.13 & 0.81 & $\times M T B$ & t-stat & 0.40 & 0.80 \\
\hline \multicolumn{2}{|l|}{$R^{2}$} & 0.11 & 0.12 & $R^{2}$ & & 0.16 & 0.24 \\
\hline \multicolumn{2}{|l|}{$p$-Value diff in $\beta_{6}$} & \multicolumn{2}{|l|}{0.00} & \multicolumn{2}{|c|}{$p$-Value diff in $\beta_{6}$} & 0.02 & \\
\hline \multicolumn{2}{|l|}{$p$-Value diff in $\beta_{6}+\beta_{7}$} & \multicolumn{2}{|l|}{0.00} & \multicolumn{2}{|c|}{$p$-Value diff in $\beta_{6}+\beta_{7}$} & 0.02 & \\
\hline
\end{tabular}

The sample consists of 9,152 firm-year observations (1,611 firms) for the years 1992 through 2003. MTB is the market-to-book value of equity ratio measured at the end of the fiscal year. In Panel A, $X$ is earnings per share before extraordinary items and discontinued operations deflated by share price at the beginning of the period. $R$ is the annual stock return measured as the continuously compounded monthly CRSP return over the firm's fiscal year. $D$ is a dummy variable that equals one in the case of bad news (negative or zero market-adjusted stock rate of return); zero otherwise. In Panel B, Accr denotes industry-adjusted annual total accruals, deflated by average assets, defined as income before extraordinary items minus cash flow from operations, where both variables are extracted from the statement of cash flows. $C F O$ is industry-adjusted cash flow from operations taken from the statement of cash flows, deflated by average assets. $D C F O$ is a dummy variable equal to one in the case of negative $C F O$ and zero otherwise

The reported $t$-statistics in italics are based on standard errors which are robust to both heteroscedasticity and within-group serial correlation. The two-sided thresholds of the $z$-statistics for significance at the $0.10,0.05$, and 0.01 confidence levels are $1.64,1.96$, and 2.61 , respectively

in the decisions of the board of directors. Our governance proxy thus incorporates external and internal governance mechanisms. It is important to include both as they have a complementary effect: external governance reinforces the effectiveness of 
internal governance and vice versa. Using a large sample of U.S. firms during the period 1992 through 2003, we find that firms with stronger corporate governance provisions in place are more conservative, as measured by our three proxies of conditional conservatism. Specifically, we show that conditional conservatism is significantly higher for firms with low antitakeover protection and low CEO involvement in board decisions. This result is robust when controlling for the investment opportunity set, as it has been shown that differences in asymmetric timeliness can be driven by differences in growth opportunities that are unrelated to conservatism (Roychowdhury and Watts 2006).

To further investigate the mechanisms managers use to prepare more conser vative accounting numbers, we also study the impact of earnings discretion on the sensitivity of earnings to bad news across governance structures. Using several accruals models, we decompose reported accruals into its discretionary and nondiscretionary components. We find that the increase in accounting conservatism in strong governance firms is driven by the discretionary component of reported accruals. This evidence is consistent with strong governance firms using accruals to accelerate the recognition of bad news in earnings.

We also investigate the direction of causality as our previous findings only document a positive association between governance and accounting conserva tism. We find that past governance is associated with current conservatism but not vice versa and that firms with increases (decreases) in governance also exhibit increases (decreases) in conservatism. Finally, we isolate an event that resulted in an exogenous shock to corporate governance, the passage of the Sarbanes Oxley Act of 2002, and use it to test the impact of changes in governance on changes in conditional conservatism. We document a substantial increase in conditional conservatism after the passage of this bill, which confirms all our previous findings.

Acknowledgements We appreciate the helpful comments and suggestions from Carol Marquardt, Antonio Dávila, Miguel Ferreira, Joachim Gassen, Christian Leuz, Flora Muino, Ivana Raonic, William Rees, Stefan Reichelstein (the editor), Phillip Stocken, Martin Walker, two anonymous reviewers, and seminar participants at the AAA 2006 Annual Meeting, EAA 2005 Annual Meeting, ACCID 2005 Annual Conference, University of Alicante, University of Valencia, IESE Business School, ISCTE Business School, London Business School, The University of Manchester, and University of Navarra (Pamplona). We acknowledge financial contribution from the Spanish Ministry of Science and Technology (SEJ200508644-C02-01/ECON). Juan Manuel García Lara also thanks the financial contribution from SECJ200409176-C02-02/ECO.

\section{Appendix 1}

Determinants of governance choice

We use the two step Heckman (1979) procedure to take into account the endogenous nature of governance. In the first stage, governance choice is modeled using a probit model. In particular, we regress a dummy variable that indicates 
whether the firm has selected either to have strong or weak governance on a set of determinants. We define strong (weak) governance as having values of Totgov below (above) the median of this variable. In the second stage, we estimate Eqs. 19 including as an additional control variable the inverse Mills ratio computed from the parameters of the first stage. The determinants of governance are taken from previous literature:

(a) Size. Larger firms are more complex and place higher demands on governance structures. Demsetz and Lehn (1985) find that size is signif icantly associated with ownership concentration. We measure size as the three year average of the natural logarithm of the market value of equity, measured at the end of the fiscal year, and predict a positive association with the quality of governance.

(b) Growth opportunities. Previous research documents that growth opportunities explain the cross sectional differences in governance configurations. Follow ing Smith and Watts (1992), our (inverse) proxy for growth is the three year average of the annual book to market value of assets ratio, measured at the end of the fiscal year. The market value of assets is defined as the market value of equity plus the book value of liabilities.

(c) Firm age. Previous research hypothesizes that the age of the firm is related to the governance structure. Following Bushman et al. (2004), our proxy is the natural logarithm of the firm's age at the end of the fiscal year, measured as the number of years the firm has been public.

(d) Free cash flow. High free cash flow poses a problem for firms with low growth opportunities, since managers may invest the excess cash in negative net present value projects or engage in empire building acquisi tions. Jensen (1986) suggests that governance structures can mitigate this agency problem. Following Lang et al. (1991), our proxy to capture this determinant is the three year average of [(operating cash flow minus preferred and common dividends)/total assets] if the book to market ratio is greater than or equal to one, and zero otherwise. Firms with book to market ratios greater than one are expected to have low growth opportunities. The free cash flow problem demands better governance, therefore we expect to find a positive association between Free cash flow and the quality of governance.

(e) Idiosyncratic risk. Demsetz and Lehn (1985) suggest that the amount of noise in the firm's operating environment is expected to increase the costs of direct monitoring, which in turn increases the demands on governance structures. These costs are expected to increase at a decreasing rate with the difficulty in monitoring. Hence, we use the logarithmic transformation of the firm's idiosyncratic risk. Idiosyncratic risk is defined as the natural logarithm of the standard deviation of the residual return from a 36 month market model regression of the firm's monthly returns on the returns to the CRSP value weighted market portfolio, imposing a minimum of 12 observations. We 
predict a positive association between Idiosyncratic risk and the quality of governance.

(f) Leverage. Cremers and Nair (2005) find that internal and external governance mechanisms are stronger complements in firms with low leverage, because higher debt reduces the probability of a takeover as the target is less attractive to the prospective acquirer. This fact reduces the governance usefulness of anti takeover mechanisms. Our proxy for leverage is the ratio of short and long term debt to total common shareholders' equity.

(g) Industry concentration and geographic concentration. Bushman et al. (2004) argue that organizational complexity increases with industry and geographic diversification. These authors hypothesize and find that the complexity associated with diversification causes costly governance responses because the inherent additional managerial difficulties generated by more complex firms place higher demands on the governance structures. To control for the level of diversification, we employ the same proxies used by Bushman et al. (2004). Industry concentration is defined as the three year average of the sum of the squares of (firm sales in each industry segment/total firm sales). Geographic concentration is defined as the three year average of the sum of squares of (firm sales in each geographic segment/total firm sales). Higher values of these two proxies indicate more industry/geographic concentration. These two proxies are inverse measures of diversification; therefore, we expect to find a negative association with the quality of governance.

(h) CEO tenure. Hermalin (2005) develops a model in which a trend towards more board diligence leads to shorter CEO tenures. Bushman et al. (2004) find that the number of years the CEO has been a director is positively associated with the presence of more inside directors in the board. Hermalin and Weisbach (1988) find that board independence declines over the course of the CEO's tenure. We hypothesize that the number of years the CEO has been in office, CEO tenure, is another determinant of governance as longer tenures increase the likelihood of having more insiders in the board. We predict a negative association between $C E O$ tenure and governance.

(i) Performance. Previous research documents the association between certain governance attributes and past firm performance. Hermalin and Weisbach (1988) find that the likelihood of independent directors being added to the board increases following poor firm performance. Similar to Demsetz and Lehn (1985), to control for past firm performance we use the three year stock return measured as the continuously compounded monthly CRSP return over 36 months, ending at fiscal year end.

(j) Regulation. The additional monitoring provided by regulators may systemat ically affect the governance characteristics of firms operating in regulated environments. Following Demsetz and Lehn (1985) and Bushman et al. (2004), we include an indicator variable that takes the value of one if the firm is a utility and zero otherwise. We do not control for financial firms because our sample excludes these firms. 
(k) High tech industry. We also include an indicator variable if the firm is in a high tech industry (Chandra et al. 2004).

(1) Quality of the auditor. The quality of the auditor may be associated with the quality of governance (Basu et al. 2001). We define an indicator variable, Big 5 , that takes on the value of one if the auditor of the firm is a Big Five auditor and zero otherwise.

The table below contains the results of the estimation of the first stage probit regression of a Heckman (1979) model. The sample consists of 9,152 firm year observations (1,611 firms) for the years 1992 through 2003. The reported $z$ statistics are based on standard errors which are robust to both heteroscedasticity and within group serial correlation. The two sided thresholds of the $z$ statistics for significance at the $0.10,0.05$, and 0.01 confidence levels are 1.64, 1.96, and 2.61, respectively.

Heckman procedure: first-stage probit regression

\begin{tabular}{|c|c|c|c|}
\hline & & Coeff. & $z$-stat \\
\hline Size $_{t} 1$ & $\beta_{1}$ & 0.02 & 1.63 \\
\hline Growth opportunities $_{t} I_{1}$ & $\beta_{2}$ & 0.21 & 2.48 \\
\hline Firm age $t_{1}$ & $\beta_{3}$ & 0.17 & 7.93 \\
\hline Free cash flow ${ }_{t}$ & $\beta_{4}$ & 4.07 & 4.20 \\
\hline Idiosyncratic risk $_{t}{ }_{1}$ & $\beta_{5}$ & 0.71 & 13.54 \\
\hline Leverage $_{t}{ }_{l}$ & $\beta_{6}$ & 0.02 & 1.35 \\
\hline Industry concentration $_{t} 1$ & $\beta_{7}$ & 0.07 & 1.25 \\
\hline Geographic concentration $_{t}{ }_{l}$ & $\beta_{8}$ & 0.26 & 4.13 \\
\hline CEO tenure $_{t}{ }_{1}$ & $\beta_{9}$ & 0.03 & 13.92 \\
\hline Performance $_{t}{ }_{1}$ & $\beta_{10}$ & 0.03 & 3.00 \\
\hline Regulation $_{t}{ }_{l}$ & $\beta_{11}$ & 0.68 & 12.38 \\
\hline Hi-tech $t_{t}$ & $\beta_{12}$ & 0.03 & 0.39 \\
\hline Big-5t 1 & $\beta_{13}$ & 0.22 & 6.14 \\
\hline Constant & $\beta_{14}$ & 1.86 & 8.81 \\
\hline Year dummies & & Yes & \\
\hline
\end{tabular}

As a sensitivity check, we also included additional variables to control for past accounting performance. In particular, we estimated specifications that included current and past return on assets, or a variable to reflect the incidence of negative earnings realizations in the past, calculated as the proportion of losses over the prior ten years. None of the inferences reported in the tables in the paper is affected by the inclusion of these variables. 


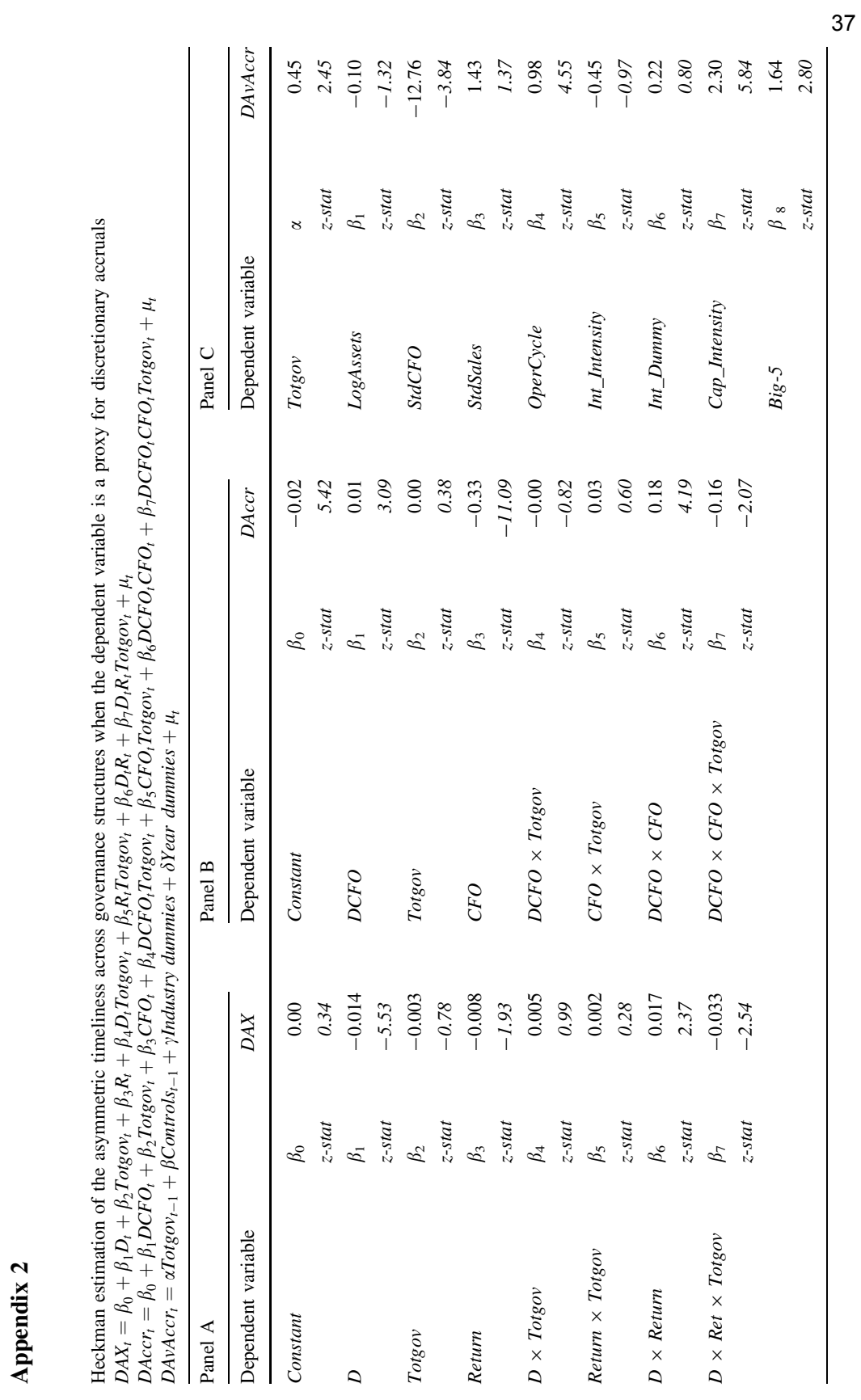




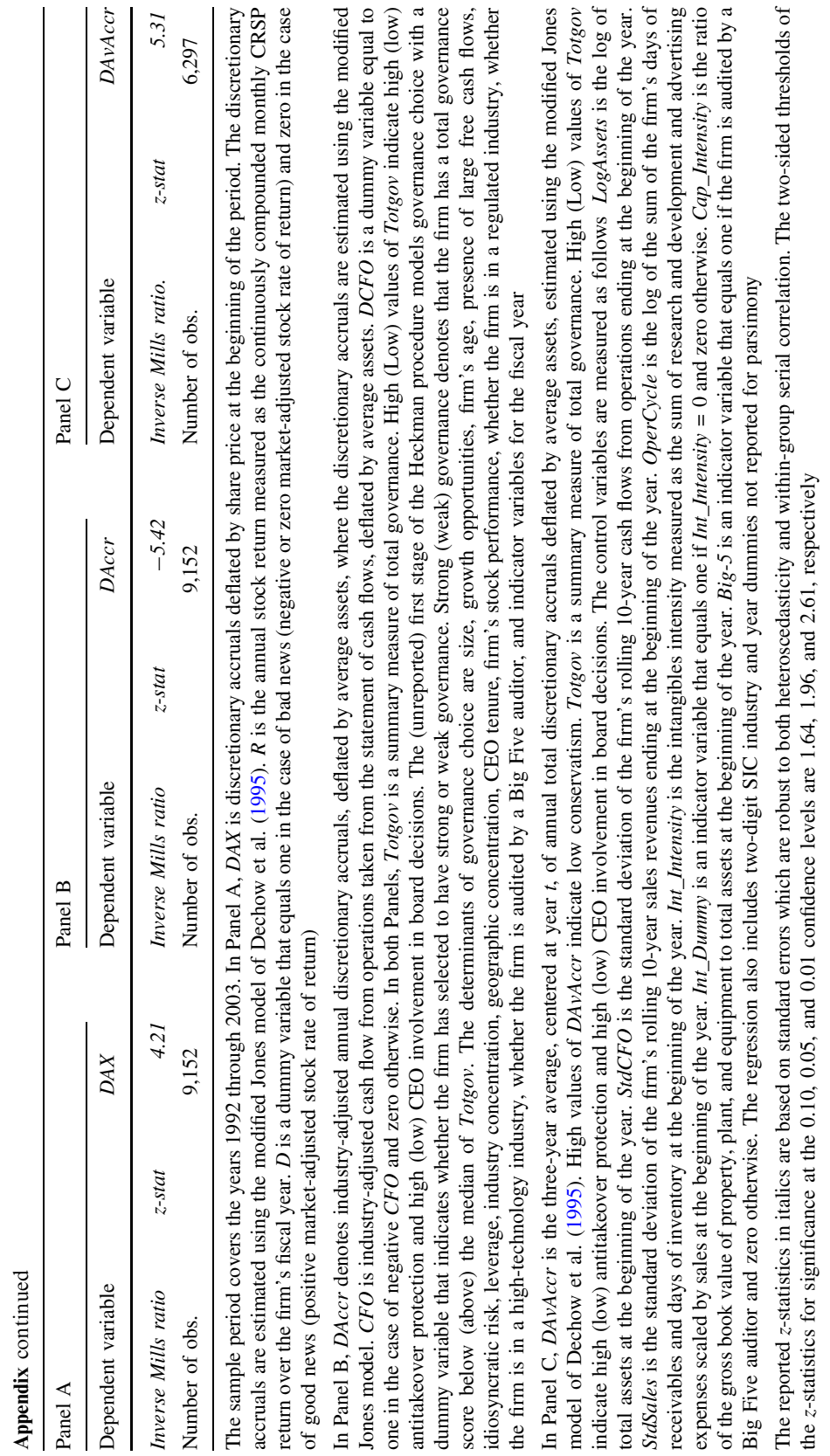




\section{References}

Abbott, L. J., Parker, S., Peters G. F., \& Raghunandan K. (2003). An empirical investigation of audit fees, nonaudit fees, and audit committees. Contemporary Accounting Research, 20, 215-234.

Adams, R. B. (2000). What do boards do? Evidence from committee meeting and director compensation. Working paper, Federal Reserve Bank of New York.

Ahmed, A. S., \& Duellman, S. (2007). Evidence on the role of accounting conservatism in corporate governance. Journal of Accounting and Economics, 43, 411-437.

Ball, R., Kothari, S. P., \& Robin, A. (2000). The effect of international institutional factors on properties of accounting earnings. Journal of Accounting and Economics, 29, 1-51.

Ball, R., Robin, A., \& Wu, J. S. (2003). Incentives versus standards: Properties of accounting in four East Asian countries. Journal of Accounting and Economics, 36, 235-270.

Ball, R., \& Shivakumar, L. (2005). Earnings quality in UK private firms: Comparative loss recognition timeliness. Journal of Accounting and Economics, 39, 83-128.

Bartov, E. (1993). The timing of asset sales and earnings manipulation. The Accounting Review, 68, 840855.

Basu, S. (1997). The conservatism principle and the asymmetric timeliness of earnings. Journal of Accounting and Economics, 24, 3-37.

Basu, S. (1999). Discussion of International differences in the timeliness, conservatism and classification of earnings. Journal of Accounting Research, 37(Supplement), 89-99.

Basu, S., Hwang, L.-S., \& Jan, C.-L. (2001). Auditor conservatism and quarterly earnings. Working Paper, City University of Hong Kong.

Beasley, M. S. (1996). An empirical analysis of the relation between the board of director composition and financial statement fraud. The Accounting Review, 71, 443-465.

Beaver, W. H., \& Ryan, S. G. (2005). Conditional and unconditional conservatism: Concepts and modeling. Review of Accounting Studies, 10, 269-309.

Becker, C., DeFond, M., Jiambalvo, J., \& Subramanyam, K. R. (1998). The effect of audit quality on earnings management. Contemporary Accounting Research, 15, 1-24.

Beekes, W., Pope, P. F., \& Young, S. (2004). The link between earnings timeliness, earnings conservatism and board composition: Evidence from the UK. Corporate Governance: An International Review, 12, 47-51.

Berle, A. A., \& Means, G. C. (1932). The modern corporation and private property. New York: McMillan Publishing Co.

Bertrand, M., \& Mullainathan, S. (2001). Are CEOs rewarded for luck? The ones without principals are. The Quarterly Journal of Economics, 116, 901-932.

Bowen, R. M., Rajgopal, S., \& Venkatachalam, M. (2004). Accounting discretion, corporate governance and firm performance. Working paper, University of Washington.

Bushee, B. J. (1998). The influence of institutional investors on myopic R\&D investment behaviour. The Accounting Review, 73, 305-333.

Bushman, R., Chen, Q., Engel, E., \& Smith, A. (2004). Financial accounting information, organizational complexity and corporate governance systems. Journal of Accounting and Economics, 37, 167-201.

Bushman, R. M., \& Piotroski, J. D. (2006). Financial reporting incentives for conservative accounting: The influence of legal and political institutions. Journal of Accounting and Economics, 42, 107-148.

Byrd, J. W., \& Hickman, K. A. (1992). Do outside directors monitor managers? Evidence from tender offer bids. Journal of Financial Economics, 32, 195-222.

Callen, J. L., Hope, O. K., \& Segal, D. (2006). The pricing of conservative accounting and the measurement of conservatism at the firm-year level. Working paper, University of Toronto.

Chandra, U., Wasley, C., \& Waymire, G. (2004). Income conservatism in the U.S. Technology Sector. Working Paper, University of Rochester.

Chung, R., Firth M., \& Kim, J.-B. (2003). Auditor conservatism and reported earnings. Accounting and Business Research, 33, 19.

Core, J. E., Holthausen, R. W., \& Larcker, D. F. (1999). Corporate governance, the executive officer compensation, and firm performance. Journal of Financial Economics, 51, 371-406.

Cremers, K. J. M., \& Nair, V. B. (2005). Governance mechanisms and equity prices. Journal of Finance, 60, 2859-2894.

Davila, A., \& Penalva, F. (2006). Governance structure and the weighting of performance measures in CEO compensation. Review of Accounting Studies, 11, 463-493. 
Dechow, P. M. (1994). Accounting earnings and cash flows as measures of firm performance: The role of accounting accruals. Journal of Accounting and Economics, 18, 3-42.

Dechow, P., \& Dichev, I. (2002). The quality of accruals and earnings: The role of accrual estimation errors. The Accounting Review 77(Supplement), 35-59.

Dechow, P. M., Sloan, R. G., \& Sweeney, A. P. (1995). Detecting earnings management. The Accounting Review, 70, 193-225.

Dechow, P. M., Sloan, R. G., \& Sweeney, A. P. (1996). Causes and consequences of earnings manipulation: An analysis of firms subject to enforcement actions by the SEC. Contemporary Accounting Research, 13, 1-36.

Demsetz, H., \& Lehn, K. (1985). The structure of corporate ownership: Causes and consequences. Journal of Political Economy, 93, 1155-1177.

Dietrich, J. R., Muller, K. A., \& Riedl, E. J. (2007). Asymmetric timeliness tests of accounting conservatism. Review of Accounting Studies, 12, 95-124.

Fama, E. F. (1980). Agency problems and the theory of the firm. Journal of Political Economy, 88, 288307.

Fama, E. F., \& Jensen, M. C. (1983). Separation of ownership and control. Journal of Law and Economics, 26, 319-337.

Fama, E., \& MacBeth, J. (1973). Risk, return, and equilibrium: Empirical tests. Journal of Political Economy, 81, 607-636.

Feltham, G. A., \& Ohlson, J. A. (1995). Valuation and clean surplus accounting for operating and financial activities. Contemporary Accounting Research, 11, 689-731.

Francis, J., LaFond, R., Olsson, P., \& Schipper, K. (2004). Cost of equity and earnings attributes. The Accounting Review, 79, 967-1010.

García Lara, J. M., García Osma, B., \& Mora, A. (2005). The effect of earnings management on the asymmetric timeliness of earnings. Journal of Business Finance and Accounting, 34, 691-726.

Givoly, D., \& Hayn, C. (2000). The changing time-series properties of earnings, cash flows and accruals: Has financial reporting become more conservative? Journal of Accounting and Economics, 29, $287-$ 320 .

Givoly, D., Hayn, C., \& Natarajan, A. (2007). Measuring reporting conservatism. The Accounting Review, $82,65-106$.

Gompers, P., Ishii, J., \& Metrick, A. (2003). Corporate governance and equity prices. The Quarterly Journal of Economics, 118, 107-155.

Grice, J. W., \& Harris, R. J. (1998). A comparison of regression and loading weights for the computation of factor scores. Multivariate Behavioral Research, 33, 221-247.

Granger C. W. J. (1969). Investigating causal relations by econometric models and cross-spectral methods. Econometrica, 37, 424-438.

Guay, W. R., Kothari, S. P., \& Watts, R. L. (1996). A market based evaluation of discretionary accruals models. Journal of Accounting Research, 34(Supplement), 83-105.

Guay, W. R., \& Verrecchia, R. (2006). Discussion of an economic framework for conservative accounting and Bushman and Piotroski (2006). Journal of Accounting and Economics, 42, 149-165.

Heckman, J. (1979). Sample selection bias as a specification error. Econometrica, 47, 153-161.

Heninger, W. G. (2001). The association between auditor litigation and abnormal accruals. The Accounting Review, 76, 111-125.

Hermalin, B. E. (2005). Trends in corporate governance. Journal of Finance, 60, 2351-2384.

Hermalin, B. E., \& Weisbach, M. S. (1988). The determinants of board composition. RAND Journal of Economics, 19, 589-606.

Hermalin, B. E., \& Weisbach, M. S. (1998). Endogenously chosen boards of directors and the monitoring of the CEO. American Economic Review, 88, 96-118.

Hermalin, B. E., \& Weisbach, M. S. (2003). Boards of directors as an endogenously determined institution: A survey of the economic literature. Economic Policy Review, 9, 7-26.

Holthausen, R. W., \& Watts, R. L. (2001). The relevance of the value relevance literature for financial accounting standard setting. Journal of Accounting and Economics, 31, 3-75.

Jensen, M. C. (1986). Agency costs of free cash flow, corporate finance, and takeovers. American Economic Review, 76, 323-329.

Jensen, M. C. (1993). The modern industrial revolution, exit and the failure of internal control systems. Journal of Finance, 48, 831-880.

Jensen, M. C., \& Meckling, W. H. (1976). Theory of the firm: Managerial behaviour, agency costs and ownership structure. Journal of Financial Economics, 3, 305-360. 
Jones, J. J. (1991). Earnings management during import relief investigations. Journal of Accounting Research, 29, 193-228.

Kasznik, R. (1999). On the association between voluntary disclosure and earnings management. Journal of Accounting Research, 37, 57-81.

Kellogg, R. L. (1984). Accounting activities, security prices, and class action lawsuits. Journal of Accounting and Economics, 6, 185-204.

Klein, A. (2002). Audit committee, board of directors' characteristics, and earnings management. Journal of Accounting and Economics, 33, 375-400.

Kothari, S. P., Leone, A. J., \& Wasley, C. E. (2005). Performance matched discretionary accrual measures. Journal of Accounting and Economics, 39, 163-197.

Lang, L., Stulz, R., \& Walkling, R. (1991). A test of the free cash flow hypothesis: The case of bidder returns. Journal of Financial Economics, 29, 315-335.

Lobo, G. L., \& Zhou, J. (2006). Did conservatism in financial reporting increase after the Sarbanes-Oxley Act? Initial evidence. Accounting Horizons, 20, 57-74.

Mikkelson, W. H., \& Partch, M. M. (1997). The decline of takeovers and disciplinary managerial turnover. Journal of Financial Economics, 44, 205-228.

Peasnell, K. V., Pope, P. F., \& Young, S. (2000). Accrual management to meet earnings targets: UK evidence pre- and post-Cadbury. British Accounting Review, 32, 415-445.

Peasnell, K. V., Pope, P. F., \& Young, S. (2005). Board monitoring and earnings management: Do outside directors influence abnormal accruals? Journal of Business Finance and Accounting, 32, 1311-1346.

Pope, P. F., \& Walker, M. (1999). International differences in the timeliness, conservatism, and classification of earnings. Journal of Accounting Research, 37(Supplement), 53-87.

Raonic, R., McLeay, S., \& Asimakopoulos, I. (2004). The timeliness of income recognition by european companies: An analysis of institutional and market complexity. Journal of Business Finance and Accounting, 31, 115-148.

Richardson, S. A., Sloan, R. G., Soliman, M. T., \& Tuna, I. A. (2005). Accrual reliability, earnings persistence and stock prices. Journal of Accounting and Economics, 39, 437-485.

Rogers, W. (1993). Regression standard errors in clustered samples. Stata Technical Bulletin Reprints (Vol. 3, pp. 83-94). College Station, TX: Stata Press.

Roychowdhury, S. (2006). Earnings management through real activities manipulation. Journal of Accounting and Economics, 42, 335-370.

Roychowdhury, S., \& Watts, R. (2006). Asymmetric timeliness of earnings, market-to-book and conservatism in financial reporting. Journal of Accounting and Economics, 44, 2-31.

Ryan, S. G. (2006). Identifying conditional conservatism. European Accounting Review, 15, 511-525.

Ryan, S. G., \& Zarowin, P. A. (2003). Why has the contemporaneous linear returns-earnings relation declined? The Accounting Review, 78, 523-553.

Shleifer, A., \& Vishny, R. W. (1986). Large shareholders and corporate control. Journal of Political Economy, 94, 461-488.

Shleifer, A., \& Vishny, R. W. (1997). A survey of corporate governance. Journal of Finance, 52, 737783.

Sims, C. A. (1972). Money, income, and causality. American Economic Review, 62, 540-552.

Smith, C., \& Watts, R. (1992). The investment opportunity set and corporate financing, dividends, and compensation policies. Journal of Financial Economics, 32, 263-292.

St Pierre, K., \& Anderson, J. A. (1984). An analysis of the factors associated with lawsuits against public accountants. The Accounting Review, 59, 242-263.

Vafeas, N. (1999). Board meeting frequency and firm performance. Journal of Financial Economics, 53, $113-143$.

Watts, R. (2003a). Conservatism in accounting. Part I. Explanations and implications. Accounting Horizons, 17, 207-221.

Watts, R. (2003b). Conservatism in accounting. Part II. Evidence and research opportunities. Accounting Horizons, 17, 287-301.

Watts, R. L., \& Zimmerman, J. L. (1986). Positive accounting theory. Upper Saddle River, New Jersey: Prentice-Hall, Inc.

Weisbach, M. S. (1988). Outside directors and CEO turnover. Journal of Financial Economics, 20, 431460. 